\title{
Shared agency: the dominant spouse's impact on education expenditure
}

\section{Article}

\section{Accepted Version}

Creative Commons: Attribution-Noncommercial-No Derivative Works 4.0

Fernandez, A. and Kambhampati, U. S. (2017) Shared agency: the dominant spouse's impact on education expenditure. World Development, 96. pp. 182-197. ISSN 0305-750X doi: https://doi.org/10.1016/j.worlddev.2017.03.006 Available at https://centaur.reading.ac.uk/69525/

It is advisable to refer to the publisher's version if you intend to cite from the work. See Guidance on citing.

To link to this article DOI: http://dx.doi.org/10.1016/j.worlddev.2017.03.006

Publisher: Elsevier

All outputs in CentAUR are protected by Intellectual Property Rights law, including copyright law. Copyright and IPR is retained by the creators or other copyright holders. Terms and conditions for use of this material are defined in the End User Agreement.

\section{www.reading.ac.uk/centaur}

\section{CentAUR}

Central Archive at the University of Reading

Reading's research outputs online 


\section{Shared agency: The dominant spouse's impact on education expenditure}

\section{Abstract:}

In this paper, we consider whether it is the gender of the decision maker or the extent of agency that they wield that is crucial to increasing household welfare. This is an important question as development policy is often formed on the basis that placing resources in the hands of women results in greater household welfare. Indonesia provides the ideal opportunity to study this issue because it is home to ethnic groups with very different gender norms from male dominance (the patrilineal Batak) to female dominance (the matrilineal Minangkabau). Using IFLS data for three rounds, we consider the impact of decision-making by the dominant spouse on household expenditure on education. We find that, in Indonesia, when the dominant spouse (male or female) has sole control of decisionmaking, there is an overall negative impact on education expenditure. This leads us to argue that it is more important to consider the issue of spousal dominance, than wholly to focus on gender. 
Keywords:

Gender; agency; household decision-making; Indonesia; ethnicity 


\section{Introduction}

In this paper, we study the impact that unequal agency within a household has on a particular aspect of household welfare, expenditure on education. There is a large literature that argues that household welfare is improved when mothers have more agency within the household (see for example Agarwal, 1997; de la Briere, Hallman, \& Quisumbing, 2003;

Duflo, 2012; Quisumbing \& Maluccio, 1999; A. Rahman, 2013; M. M. Rahman, Mostofa, \& Hoque, 2014; Seebens \& Sauer, 2007). Since this literature is predicated on the dominant patriarchal, patrilineal model of households, these results have been interpreted to mean that increasing women's agency will improve household welfare. This leaves open the issue of whether it is gender which is important or an increase in agency for the less dominant spouse (men in matrilineal societies and women in patrilineal societies). This is what we analyze in this paper using data from Indonesia.

Indonesia provides the ideal opportunity to study this issue because it is home to ethnic groups with very different gender norms (Blackburn, 2004) ranging from the patrilineal (Batak) to the bilateral (Javanese) and the matrilineal (Minangkabau).The Indonesia Family Life Survey (IFLS), which we use in this paper, provides information at the household and community level allowing us to analyze the impact of agency within the household across a range of kinship systems. In this context, we consider whether there is any symmetry between the agency wielded by the 'weaker' partner amongst the patrilineal Batak (women) and the matrilineal Minangkabau (men). We ask whether women are less powerful than men in making certain decisions even within the matrilineal Minangkabau. We also ask whether the power wielded by the dominant spouse has different impacts across these groups. Our results indicate that cooperation between the partners is more beneficial in 
Indonesia than enhancing the power of either parent in the household, particularly where that parent is already powerful. Our findings confirm those of Basu and Ray (2002) who found that, in the context of child labor, household welfare was greatest in households where both parents were equally powerful.

Our paper makes several contributions to the literature. First, while there is a lot of research on women's agency in developing countries, there is much less on shared agency between spouses. There is also less literature analyzing the agency wielded by men when they are the 'weaker' partner. This is not surprising, given that many systems across the world are patrilineal and patriarchal. In this paper, we use the different kinship systems in Indonesia to study the impact of agency (of both men and women) on household expenditure on education and the heterogeneity of this agency across communities.

Secondly, our analysis enables us to explicitly consider the role of female decision-making and compare it with that of men. There is some evidence (Ashraf, 2009; Gneezy, Leonard, \& List, 2009) that there are parallels amongst women in matrilineal societies and men in patrilineal societies. Ashraf (2009), for instance, finds that "women whose husbands control the savings decisions in the household behave as the men whose wives control the savings decision" (p.1247). In the context of a country like Indonesia where there is greater balance with regards to agency between men and women, such an analysis is likely to be especially revealing.

Our third contribution is methodological. The study of women's agency has, until recently, used indirect proxies like the relative income, the relative education or the relative age of spouses as a proxy for the power they wield in making decisions within the household 
(Anderson \& Eswaran, 2009; Felkey, 2013; Quisumbing, 2003). More recently, with the popularity of the Demographic and Health Surveys (DHS) datasets, researchers have measured women's agency through responses to questions about their freedom to move outside the home, their ability to make decisions regarding child health or their acceptance of violence from partners (for example Agarwal, 1997; Aizer, 2010; Jejeebhoy, 2002). While the DHS measures are very revealing of autonomy in some contexts, they have been criticized for ignoring the increased responsibility that such freedoms entail for women. Basu and Koolwal (2005), for instance, argue that the real measure of autonomy is not whether women have the freedom to do certain things but what would happen if a woman chose to ignore these freedoms. In particular, they conclude that true freedom requires some measure of self-indulgence and the freedom to do relatively unproductive things (listen to radio, visit friends) and to set aside money for personal use, for example. In this paper, we use a different, more direct agency measure - the decisions made by men and women across different domains within the household. While other researchers (Anderson \& Eswaran, 2009; Fernandez, Della Giusta, \& Kambhampati, 2015; Garikipati, 2008; Rammohan \& Johar, 2009) have used this measure, it is relatively underused despite providing us with a direct measure of the impact that female agency has on the quality of decisions within the household.

We structure our paper as follows. We begin with a review of the literature that we draw on, focusing on the concepts of agency, gender and ethnicity in Section 2. We then describe our data and methodology in Section 3 before moving on to the results in Section 4 and the discussion in Section 5. 


\section{Literature Review}

\subsection{Gender and agency}

In this paper, we focus on a particular form of power, agency, which refers to an individual's ability to act on a goal deemed to be important (Iversen, 2003; Kabeer, 1999; A. Sen, 1985, 2001) and to make strategic life choices (Kabeer, 1999). We measure agency by analyzing decisions made within households.

Unlike the early unitary models (see Becker, 1974; Becker, 1981), it is now commonly accepted that a household is not a unitary entity governed by a single decision-maker. Household interactions seldom take the binary form of either cooperation or discord which is central to many bargaining models because "the simultaneity of cooperation and conflict in gender divisions has often been trivialized in the formal economic literature" (Sen, 1990, p.131). Sen therefore proposed the idea of cooperative conflict, where household members cooperate (and thereby add to the total resources available to the household) and experience conflict (the process of dividing these resources) (Sen, 1987b, 1990). Of course, there is no single co-operative outcome and a person's ability to bargain (often gendered and affected by perceived contributions to the household) is crucial in how they fare in the co-operative outcome. Within these models, women are seen as more concerned about family welfare than their own (Sen, 1987a).

Sen's co-operative conflict model has been criticized for attributing false consciousness to women (Jackson, 2013). Agarwal (1997) also argues that women identify their personal welfare with that of their husband and children because they are socialized towards meeting collective needs. She illustrates this through a comparison of the matrilineal and 
matrilocal Khaasi group in India and their patrilineal and patrilocal peers. Experimental evidence (Iversen, Jackson, Kebede, Munro, \& Verschoor, 2011) reinforces these findings that women neither identify more with household interests nor, therefore, do they contribute more to the common pool than men. Jackson (2013) concludes that "the complex interdependencies of husbands and wives in diverse ethnographies suggest a more uncertain balance of power within a marriage than the co-operative conflict model implies". In research on South Asia, Furuta and Salway (2006) argue that spousal autonomy is further circumscribed by interdependencies across and within families.

The family sociology literature (Rosenbluth, Steil, \& Whitcomb, 1998) sees decision making as a measure of relationship equality with a number of studies concluding that equal sharing in decision making is beneficial for relationships (Gray-Little \& Burks, 1983; Lange \& Worrell, 1990). However, the literature distinguishes between significant and less important decisions. Thus, Safilios-Rothschild (1970) talked of 'orchestration power' (making important decisions which do not infringe on a partner's time but affect the household's lifestyle) and 'implementation power' (the time consuming but less important decisions). In Western middle class families, for instance, routine housekeeping decisions were made by the wife but career-related decisions were made by the husband (Edgell, 1980; Steil \& Weltman, 1991). Similarly, Fox and Murry (2000) conclude that although couples might see their marriages as equal and their family roles as egalitarian, husbands were more likely to retain an upper hand in decision making processes. Only rarely (Bartley, Blanton, \& Gilliard, 2005) do wives see themselves as exerting more influence than their husbands in dual career households. 
In the context of developing countries, Basu and Ray (2002) find that child labor in Nepal is least likely to occur in households where there is a balance of power between spouses. They extend a collective bargaining model to include child labor and hypothesize a U-shaped relationship between women's agency and child labor - in other words, as women's agency increases, child labor will fall initially and then rise (see also Basu, 2006). They begin with the assumption that both parents dislike sending their children out to work. Their result hinges on the fact that when both spouses are equally powerful, neither the father nor the mother benefits exclusively from the additional income earned by their children. Rammohan and Robertson (2012) also find that educational outcomes are better in communities where the norms favor equal inheritance.

Using earlier rounds of the IFLS dataset that we use in this paper, Beegle, Frankenberg, and Thomas (2001) analyze the impact of bargaining power on prenatal and delivery care in Indonesia. Their measure of bargaining power is based on relative ownership of assets by the partners, their relative education and family backgrounds (which are seen to determine outside options). They find that while the distribution of economic power within a household significantly influences prenatal and delivery care, the impact of relative education and family background is mixed. They conclude that "power is multifaceted and each indicator captures a different dimension of the complex interactions that take place between husband and wife as they negotiate investments in reproductive health" (p.143). More recent studies have used more direct measures of agency (Adato, Brière, Mindek, \& Quisumbing, 2003; Fernandez et al., 2015; Mabsout \& van Staveren, 2010; Quisumbing, 2003) facilitated by the availability of household decision-making data. Analyzing the use of maternal health services in Bangladesh using this measure, Story and Burgard (2012) find 
the husband's involvement in decision making is especially important because male decisions on large household purchases and husband only decision making is less beneficial to the use of maternal health services than joint decision making. A number of other studies have suggested that greater equality in decision making (Kabeer, 2001) or joint household decision making (Mullany, Hindin, \& Becker, 2005) may yield better outcomes.

For the purposes of this research, we focus on three main ethnic groups, the patriarchal and patrilineal Batak, the bilateral Javanese and the matrilineal Minangkabau.

\subsection{Kinship systems in Indonesia}

Indonesia is culturally diverse and made up of hundreds of ethnic groups (Sakai, 2010; Statistics Indonesia \& Macro International, 2008). While women in Indonesia are frequently said to have more agency than South or East Asian women (Bulbeck, 1997; Koning, Nolten, Rodenburg, \& Saptari, 2000; Saptari, 2000), this differs across ethnic groups. In this research, we focus on three groups - the Batak, the Javanese and the Minangkabau - which represent very different social structures. The Javanese are largely bilateral in terms of kingroup while the Batak are strongly patriarchal and patrilineal and the Minangkabau are matrilineal. These broad descriptors obscure considerable heterogeneity within groups. In this paper, however, we highlight the systematic regularities within each group while acknowledging the differences across them. We will consider each of these groups in more detail in the rest of this section before we turn to our analysis of the impact of decision making within these groups. 


\subsubsection{The Javanese}

Javanese women are often said to be relatively more powerful than many of their counterparts from other ethnic groups. This is typically attributed to their economic prowess, role as managers of their households, ability to earn as much as, if not more than, their spouses and their equal inheritance rights (Brenner, 1995; Geertz, 1961; Hatley, 1990; Keeler, 1990; Kevane \& Levine, 2000; Weix, 2000) though this view is not without its critics (Brenner, 1995; Koning, 2004; Koning et al., 2000; Wolf, 2000).

Javanese husbands are expected to give the majority (if not all) of their earnings to their wives for use in managing the household (Brenner, 1995). In the event of divorce, Javanese women take with them all the property that they brought to the marriage and are entitled to half of all jointly owned property and assets (Brenner, 1995). But, traditionally fathers have the final say with regards to key decisions such as their children's marriage, education and employment (Elmhirst, 2000). In recent years, Javanese women have been increasingly confronted with a patriarchal state ideology which ignores the multiplicity of their roles as family provider, wife, mother and spouse as well as any community roles they might have as elders or leaders (Koning, 2004). Studies also suggest the ideal Javanese woman is expected to focus on all aspects of men's comfort: she should be faithful to her spouse but willing to share him with other women, caring and attentive to her family and in-laws, skilled at women's work, simple and good at making herself beautiful and fulfilling men's desires (Astuti, 2005). This suggests that while we might expect Javanese women to have significant agency in economic decision making, this agency is also increasingly circumscribed by social and legal norms in other spheres of life. 


\subsubsection{The Batak}

There are six Batak communities around Lake Toba. While there is significant diversity amongst these groups, all are patriarchal and patrilineal, with daughters seen as less entitled to education than sons (Kevane \& Levine, 2000) and excluded from inheriting land and assets (Kevane \& Levine, 2000; Portier \& Slaats, 1987; Rodenburg, 2000). Even after marriage, women retain practical responsibilities for their patrilineal kin-group including mediating on inheritance issues despite being unable to inherit themselves (Portier \& Slaats, 1987).

Batak women are typically the least empowered if judged by their access to resources, their rights over property and children and their mobility and residence. They must defer to their male elders in all important decisions. On divorce, they lose their rights to their children and to joint property and assets if they initiate the divorce (Rodenburg, 2000). While it is possible for women to ask for support and help from their brothers, this is a precarious safety net as, in the event of a refusal, women are expected to accept the rejection and avoid public confrontation (Rodenburg, 2000).

\subsubsection{The Minangkabau}

The Minangkabau, based predominantly in West Sumatra, form the second largest matrilineal population in the world (Kreager \& Schroder-Butterfill, 2009). Women inherit and hold ancestral land, control economic production and are household heads. Men cannot inherit ancestral land and matrilines without daughters face extinction (Kreager \& Schroder-Butterfill, 2009; Schwede, 1991). Both matrilineal descent and Islam are seen as being as of equal importance (Esten, 1993; Sanday, 2002). A large extended family of several 
sub-lineages typically lives together with each nuclear family operating separately on some issues but coming together for kin-group decisions (Blackwood, 1995; Ihromi, 2005; Schwede, 1991).

Minangkabau men do not have authority independent of the lineage but can exercise authority as the titular male representative ('penghulu') (Blackwood, 1995). In recent years, state laws have eroded Minangkabau women's traditional inheritance rights (Noerdin, 2002) and male 'adat' ${ }^{1}$ experts have reinforced these changes by downplaying the authority and role of senior women (Blackwood, 1995). This has been exacerbated by agricultural extension programs which attempt to impose patriarchal views by treating the men who work on their wives' land as the landholders (Blackwood 1995).

Young Minangkabau men are expected to migrate in search of their living to prove their worth (Kreager \& Schroder-Butterfill, 2009) with education opening new opportunities away from agriculture for men (Reenen, 2000). Daughters traditionally remain in the village and live in their maternal homes on marriage. This has begun to change in recent years with more young women migrating in search of employment (Blackwood, 2007; Kreager \& Schroder-Butterfill, 2009; Reenen, 2000). Husbands are seen as 'guests' in the homes of their wives as long as they pull their weight financially but Minangkabau marriages are evolving towards nuclear households living away from the wife's matrikin (Chadwick, 1991).

\footnotetext{
${ }^{1}$ This refers to custom and ethnicity based legal systems in Indonesia that govern a range of rights, obligations and expectations such as marriage and inheritance. 'Adat' laws remain very important despite the existence of religious and state legal systems (Buttenheim \& Nobles, 2009).
} 
Men are often described as caught between their conjugal families and their matrikin (Kreager \& Schroder-Butterfill, 2009; Sanday, 2002). Men's income typically pays for their children's education with any excess income going to their maternal families (Blackwood, 1995). Traditionally, maternal uncles had more authority within a matrikin than husbands and fathers (Kreager \& Schroder-Butterfill, 2009; Sanday, 2002) but this is changing with husbands increasingly taking over economic obligations (Reenen, 2000; Schwede, 1991), providing both an important source of labor on their wife's farms (Chadwick, 1991) and greater access to the market (Reenen, 2000). Despite these recent changes, however, the Minangkabau remain the group within which we might expect women to have the greatest agency in household decision making.

As seen from the discussion above, there is considerable variation in gender roles and norms across the different ethnic groups (Blackburn, 2004) in Indonesia which makes it an ideal case in which to study women's agency. There are also significant differences within each group and changes over time. In this paper, however, we focus on the differences between, rather than within, each group and control for changes over time by including time dummies.

\section{Data and methodology}

\subsection{The data}

The IFLS is a representative, continuing longitudinal socioeconomic and health survey which has data on a broad range of demographic, social and economic issues including household decision-making (Frankenberg et al., 1995). The households included in the survey are taken from half of the 26 provinces, both rural and urban, and are representative of $83 \%$ of the 
Indonesian population. Each wave of the IFLS has been administered to both the original households and to any split-offs from those households with a re-contact rate of $90.6 \%$ (Strauss, Witoelar, Sikoki, \& Wattie, 2009). There are four waves of the IFLS - 1993, 1997, $2000,2007 / 8$ - and the data used here forms an unbalanced panel spanning three time periods. We do not use data from IFLS1 as household decision-making information was not collected during the first wave. Several people in each household were interviewed, though the household decision-making questions were administered only to married couples, with both the household head and his or her spouse being interviewed (Strauss et al., 2009). The data identified the person making decisions within each household: fathers, mothers, jointly by both spouses or by other family members. In general, a very small proportion of decisions were made by parties other than the parents in this dataset. ${ }^{2}$

In this paper, we include only households where both spouses are from the same ethnic group as in marriages across ethnic groups the dominant norms are likely to be unclear. We acknowledge that, as a result, the households in our research might be more conservative but feel this is appropriate as mixed marriages, in particular between the Batak and the Minangkabau, warrant a separate study. As we are interested in the impact of mothers' and fathers' decision-making on education expenditure within households, we exclude households with non-biological, school-aged children such as grandchildren or nieces and nephews. We also excluded 879 households where spouses entered or left (usually because of divorce or death).

\footnotetext{
${ }^{2}$ Less than $10 \%$ of decisions relating to large household expenditure and small household expenditure were made by other decision-makers. Less than $15 \%$ of decisions relating to children and cash or gift-giving were made by other decision-makers while only a third of savings related decisions had no input from other decision-makers.
} 


\subsection{The methodology}

Our main research question is the extent to which the agency of the less dominant spouse might influence household expenditure on education. We also consider whether there is any symmetry between how women's agency functions in a patrilineal group and men's agency in a matrilineal group and ask what impact this might have on household expenditure on education.

\subsubsection{The dependent variable}

Our dependent variable is household expenditure on education, chosen as a measure of household welfare in Indonesia. While household welfare covers adult/child nutrition, children's education, anthropometric measures, mobility or ownership of assets, we concentrate on educational expenditure for two reasons. First, education is seen as a significant factor in inter-generational economic and welfare outcomes and has therefore also been prioritized in the MDGs. Second, there is very little variability across households in Indonesia on measures like child vaccination rates or the number of meals eaten in a day by children, ${ }^{3}$ while prenatal care and maternal health has been studied by (Beegle et al., 2001) using the same dataset.

\footnotetext{
${ }^{3}$ Using IFLS4, there was little variability in child vaccination rates which are relatively high in Indonesia $(86.5 \%$ for BCG, $88.3 \%$ for polio, $83.6 \%$ for DPT, $77.5 \%$ for measles, $78.2 \%$ for Hepatitis B while $82.5 \%$ received Vitamin A supplements). With regards to food type and consumption, there was a lack of variability in the data with over $96.0 \%$ of children consuming at least two meals a day.
} 
Education in Indonesia is compulsory up to the age of 15 and while free education ${ }^{4}$ is theoretically available, public schools levy a range of unofficial fees to cover costs (Kattan \& Burnett, 2004; King, McGrath, \& Rose, 2007). Parental fees and contributions constitute about $8 \%$ of school funding and there is social pressure on families to support schools (James, King, \& Suryadi, 1996).

Household expenditure on education as a proportion of total household expenditure therefore varies considerably across households (see Table 1 below). While there is no significant difference in average spending on education between the Batak and Minangkabau groups, there are statistically significant (albeit small) differences between the patrilineal Batak and the bilateral Javanese and between the Javanese and the Minangkabau. In our empirical analysis, we will consider these differences in more detail.

Table 1 Mean of annual household education expenditure per school age child by ethnicity

\begin{tabular}{|l|c|c|c|c|c|c|}
\hline \multirow{2}{*}{ Variable } & \multicolumn{2}{|c|}{$\begin{array}{c}\text { Comparison of Batak } \\
\text { and Javanese }\end{array}$} & \multicolumn{2}{c|}{$\begin{array}{c}\text { Comparison of Batak } \\
\text { and Minangkabau }\end{array}$} & \multicolumn{2}{c|}{$\begin{array}{c}\text { Comparison of Javanese } \\
\text { and Minangkabau }\end{array}$} \\
\cline { 2 - 7 } & $\begin{array}{c}\text { Difference } \\
\text { of means }\end{array}$ & $\begin{array}{c}\mathrm{t} \text { - } \\
\text { statistics }\end{array}$ & $\begin{array}{c}\text { Difference } \\
\text { of means }\end{array}$ & $\begin{array}{c}\mathrm{t}- \\
\text { statistics }\end{array}$ & $\begin{array}{c}\text { Difference } \\
\text { of means }\end{array}$ & $\begin{array}{c}\mathrm{t}- \\
\text { statistics }\end{array}$ \\
\hline $\begin{array}{l}\text { Nominal total } \\
\text { education expenditure }\end{array}$ & $1,809,892$ & 4.6687 & $-129,570$ & -0.0688 & $-1,939,462$ & -3.8060 \\
$\begin{array}{l}\text { Real total education } \\
\text { expenditure }\end{array}$ & $1,108,663$ & 4.6352 & $-86,740$ & -0.0745 & $-1,195,403$ & -3.7978 \\
\hline
\end{tabular}

\footnotetext{
${ }^{4}$ Primary and junior high school education was made free in 2005 but entry into the scheme was voluntary and schools that entered the scheme faced gaps between running costs and the funding received from the government.
} 
Our preferred model ${ }^{5}$ is:

$$
\text { hhexpht }=\beta_{1} x_{1 h t}+\beta_{2} x_{2 h t}+\beta_{3} x_{3 h t}+\mu_{h t}
$$

Where hhexp denotes the proportion of total household expenditure spent on education; $\mathrm{h}$ denotes a household $(i=1,2, \ldots . . N) ; \beta_{k}$ denotes the vector of parameters to be estimated $(k=1, \ldots 4) ; x_{1}$ includes demographic characteristics (ethnicity, religion, parental education, number of children), $x_{2}$ is financial resources (log of household income,${ }^{6}$ parental employment status and asset ownership ${ }^{7}$ ), and $x_{3}$, the autonomy variables.

The model is estimated in two ways. In the first case, our autonomy variable $\left(x_{3}\right)$ is proxied by the relative age, income and education of the spouses which capture differences between the spouses. While these are blunt measures we include them in our preliminary estimation to provide a comparator to existing studies in the literature. Since relative education is time invariant, we estimate this model by including dummies for time (Table 4). This allows us to retain the time invariant variables in the model while also controlling for changes in economic, social and gender relations over time. This was a period of considerable change in Indonesia with the fall of the Soeharto government, the Asian financial crisis and changing gender attitudes within ethnic groups as discussed in Section 2.2. and the election of the country's first female President, Megawati Sukarnoputri. Despite the heterogeneity of social and gender norms ${ }^{8}$ across ethnic groups, the state is active in

\footnotetext{
${ }^{5}$ We eliminate the unobserved household fixed effect using a within group fixed effect method, eliminating $\alpha_{\mathrm{h}}$ from the equation hhexpht $=x^{\prime}{ }_{h t} \beta+\alpha_{h}+\varepsilon_{h t}$

${ }^{6}$ Household income is the log of total household income adjusted for inflation with IFLS2 used as the base. The IFLS collected data on wage related and non-wage related income.

${ }^{7}$ Asset ownership is a binary variable for home ownership.

${ }^{8}$ Norms here refer to expected and accepted ways of behaving within a particular society.
} 
seeking to define gender roles (Jones, 2002; O'Shaughnessy, 2009), making households a locus of the conflict between official ideologies of gender relations ${ }^{9}$ and the multiplicity of indigenous gender identities, ${ }^{10}$ to varying extents (Blackburn, 2004; Blackwood, 1995; Jones, 2002; Koning et al., 2000; Krier, 1995; O'Shaughnessy, 2009; Pfau-Effinger, 1998, 2004; Reenen, 2000; K. Sen, 1998). The time dummies in the estimations in Table 4 capture some of these effects.

The second measure of decision making within the household is our preferred measure which provides a more nuanced and direct autonomy variable. These decision-making variables are time variant and capture many of the changes discussed above at household level. They also allow us to estimate this model with panel fixed effects methods. ${ }^{11}$ Our choice of fixed (rather than random) effects was confirmed by the Hausman test and reduces the problem of unobserved heterogeneity.

We discuss these agency variables in more detail in the next section.

\subsubsection{Measuring agency}

Indirect measures of agency

\footnotetext{
${ }^{9}$ This refers to State sponsored beliefs of appropriate behaviour for men and women either legally enshrined as in the 1974 Marriage Law or via propaganda like State lbu-ism.

${ }^{10}$ This refers to a person's sense of self.

${ }^{11}$ We are aware that fixed effects make a strong assumption of strict exogeneity. However, as the IFLS waves were not carried out in consecutive years with a gap of three years between IFLS2 and IFLS3 and seven years between IFLS3 and IFLS4, this gives a close enough approximation to strict exogeneity.
} 
Table 2 Overall mean of relative income, education and age by ethnicity

\begin{tabular}{|c|c|c|c|c|c|c|c|c|c|c|}
\hline \multirow[t]{2}{*}{ Variable } & \multirow[t]{2}{*}{ Definition } & \multirow{2}{*}{$\begin{array}{l}\text { Batak } \\
\text { Mean }\end{array}$} & \multirow{2}{*}{$\begin{array}{c}\text { Javanese } \\
\text { Mean }\end{array}$} & \multirow{2}{*}{$\begin{array}{c}\text { Minangkabau } \\
\text { Mean }\end{array}$} & \multicolumn{2}{|c|}{$\begin{array}{c}\text { Comparison of Batak } \\
\text { and Javanese }\end{array}$} & \multicolumn{2}{|c|}{$\begin{array}{l}\text { Comparison of Batak } \\
\text { and Minangkabau }\end{array}$} & \multicolumn{2}{|c|}{$\begin{array}{l}\text { Comparison of } \\
\text { Javanese and } \\
\text { Minangkabau }\end{array}$} \\
\hline & & & & & $\begin{array}{l}\text { Difference } \\
\text { of means }\end{array}$ & t-statistics & $\begin{array}{l}\text { Difference } \\
\text { of means }\end{array}$ & $\begin{array}{c}\mathrm{t}- \\
\text { statistics }\end{array}$ & $\begin{array}{l}\text { Difference } \\
\text { of means }\end{array}$ & $\begin{array}{c}\mathrm{t}- \\
\text { statistics }\end{array}$ \\
\hline $\begin{array}{l}\text { Relative } \\
\text { income }\end{array}$ & $\begin{array}{l}\text { Ratio of mother's } \\
\text { income to } \\
\text { household income }\end{array}$ & 0.3055 & 0.3374 & 0.3610 & -0.0319 & -1.7445 & -0.0555 & -2.0455 & -0.0236 & -1.3078 \\
\hline Relative age & $\begin{array}{l}\text { Ratio of mother's } \\
\text { age to father's age }\end{array}$ & 0.9301 & 0.8807 & 0.8914 & 0.0494 & 10.2852 & 0.0387 & 6.0093 & -0.0107 & -2.3626 \\
\hline
\end{tabular}

${ }^{*}$ This measure reflects percentage $=1$ 


\section{Relative income}

Relative income has been used as a proxy for women's agency because it can affect how much bargaining power each spouse has within the household (Felkey, 2013; Kambhampati, 2009). However, this variable is problematic because it is endogenous to decisions made within the household (Basu, 2006) and it also cannot capture cooperative and competitive interests in the household or slow moving social norms (Mabsout \& van Staveren, 2010). In recent years, therefore, this variable has fallen out of favor. Despite this, we begin with an estimation that includes this variable to provide comparability with existing studies. We formulate relative income as the ratio of mothers' income to household income using wage income from the previous year. As expected, Minangkabau mothers contributed the largest proportion of household income (about 36\%) followed by the Javanese (34\%) and Batak (31\%). These differences are statistically significant (Table 2) confirming that, as measured by their contribution to household income, Batak women have the least agency amongst our three groups. Also, despite being matrilineal, Minangkabau women do not contribute more than their husbands.

\section{Relative education}

Relative education has been used to measure female autonomy (Andersen, Bulte, Gneezy, \& List, 2008; Anderson \& Eswaran, 2009; Basu \& Ray, 2002; Imai, Annim, Kulkarni, \& Gaiha, 2014; Mabsout \& van Staveren, 2010; Quisumbing, 2003) because educated women are seen as having outside options and as better able to bargain effectively within the household. This variable takes a value of one where the mothers' education level is higher based on the highest level of schooling completed by both spouses. Across all ethnic groups, 
only $13 \%$ of the women had more education than their spouses although this varies from $12 \%$ for the Javanese to $15 \%$ for the Batak and $22 \%$ for the Minangkabau. As expected, although more Minangkabau women are better educated than their spouse compared to Batak and Javanese women, the majority of men in all the groups are better educated than their wives. Since education is largely undertaken prior to marriage, this variable is likely to be exogenous but time invariant necessitating a pooled estimation with time dummies.

\section{Relative age}

Women who are younger than their husbands are likely to have less agency and independence, especially in Indonesia where power is linked to gender and seniority. We include relative age as the ratio of mothers' to fathers' age (Anderson \& Eswaran, 2009; Kritz \& Makinwa-Adebusoye, 1999; Mabsout \& van Staveren, 2010), so a value of one indicates husbands and wives are the same age and values greater than one indicate women are older than their husbands. There are significant differences across the groups, with Batak women being closer in age to their husbands than either Javanese or Minangkabau women. This could indicate that Batak women have more agency compared to Javanese and Minangkabau women, using this particular measure.

We include these measures in our first estimation (Table 4) which enables comparison with results from existing literature. Before we do this, we consider our preferred agency variables in the next section. 
Direct measures of agency

We now turn to household decision making, a more direct measure of agency (Anderson \& Eswaran, 2009; Garikipati, 2008; Jejeebhoy, 2002; Rammohan \& Johar, 2009). We chose this measure as it reflects the influence and authority each spouse wields (Anderson \& Eswaran, 2009).

Decision-making in this paper broadly covers two household domains: child-related decisions $\mathrm{s}^{12}$ and financial decisions (on large and small ${ }^{13}$ household expenditures, cash and gift-giving ${ }^{14}$ and savings). Our decision-making variables are a series of dummy variables for decisions made solely by fathers, solely by mothers or jointly with their spouse. We estimate a separate regression for each of these decision-makers. We will discuss these variables in more detail below in two categories - decisions relating to finances and to children.

\footnotetext{
${ }^{12}$ This is education, health and clothing.

${ }^{13}$ Small expenditure is food and on routine household purchases.

${ }^{14}$ This is to own family and in-laws and gift giving for celebrations.
} 
Table 3a Descriptive statistics for father-only decision-making variables by ethnicity

\begin{tabular}{|c|c|c|c|c|c|c|c|c|c|c|c|}
\hline \multirow[t]{2}{*}{ VARIABLES } & \multicolumn{11}{|c|}{ Father-only decisions } \\
\hline & $\begin{array}{l}\text { Children's } \\
\text { clothes }\end{array}$ & $\begin{array}{l}\text { Children's } \\
\text { education }\end{array}$ & $\begin{array}{l}\text { Children's } \\
\text { health }\end{array}$ & $\begin{array}{l}\text { Monthly } \\
\text { ROSCA }\end{array}$ & $\begin{array}{l}\text { Monthly } \\
\text { savings }\end{array}$ & $\begin{array}{l}\text { Food } \\
\text { expenditure } \\
\text { at home }\end{array}$ & $\begin{array}{l}\text { Routine } \\
\text { household } \\
\text { purchases }\end{array}$ & $\begin{array}{l}\text { Giving } \\
\text { money to } \\
\text { own family }\end{array}$ & $\begin{array}{l}\text { Giving } \\
\text { money to } \\
\text { in-laws }\end{array}$ & $\begin{array}{l}\text { Giving } \\
\text { gifts }\end{array}$ & $\begin{array}{l}\text { Large, } \\
\text { expensive } \\
\text { household } \\
\text { purchases }\end{array}$ \\
\hline All ethnicities & $5.41 \%$ & $8.72 \%$ & $7.40 \%$ & $5.72 \%$ & $7.46 \%$ & $8.26 \%$ & $6.89 \%$ & $10.28 \%$ & $6.64 \%$ & $8.07 \%$ & $15.09 \%$ \\
\hline Batak & $4.48 \%$ & $5.66 \%$ & $4.01 \%$ & $3.08 \%$ & $4.74 \%$ & $4.48 \%$ & $6.13 \%$ & $6.15 \%$ & $5.20 \%$ & $6.37 \%$ & $13.48 \%$ \\
\hline Javanese & $4.62 \%$ & $8.01 \%$ & $7.03 \%$ & $7.42 \%$ & $8.05 \%$ & $8.12 \%$ & $6.53 \%$ & $10.55 \%$ & $7.25 \%$ & $8.85 \%$ & $15.01 \%$ \\
\hline Minangkabau & $7.61 \%$ & $9.47 \%$ & $7.41 \%$ & $3.09 \%$ & $7.82 \%$ & $17.28 \%$ & $11.52 \%$ & $18.52 \%$ & $7.61 \%$ & $9.07 \%$ & $15.29 \%$ \\
\hline
\end{tabular}

Table 3b Descriptive statistics for mother-only decision-making variables by ethnicity

\begin{tabular}{|c|c|c|c|c|c|c|c|c|c|c|c|}
\hline \multirow[t]{2}{*}{ VARIABLES } & \multicolumn{11}{|c|}{ Mother-only decisions } \\
\hline & $\begin{array}{l}\text { Children's } \\
\text { clothes }\end{array}$ & $\begin{array}{l}\text { Children's } \\
\text { education }\end{array}$ & $\begin{array}{l}\text { Children's } \\
\text { health }\end{array}$ & $\begin{array}{l}\text { Monthly } \\
\text { ROSCA }\end{array}$ & $\begin{array}{l}\text { Monthly } \\
\text { savings }\end{array}$ & $\begin{array}{l}\text { Food } \\
\text { expenditure } \\
\text { at home }\end{array}$ & $\begin{array}{l}\text { Routine } \\
\text { household } \\
\text { purchases }\end{array}$ & $\begin{array}{l}\text { Giving } \\
\text { money to } \\
\text { own family }\end{array}$ & $\begin{array}{l}\text { Giving } \\
\text { money to } \\
\text { in-laws }\end{array}$ & $\begin{array}{l}\text { Giving } \\
\text { gifts }\end{array}$ & $\begin{array}{l}\text { Large, } \\
\text { expensive } \\
\text { household } \\
\text { purchases }\end{array}$ \\
\hline All ethnicities & $29.21 \%$ & $10.24 \%$ & $12.89 \%$ & $21.35 \%$ & $10.36 \%$ & $69.97 \%$ & $68.71 \%$ & $9.09 \%$ & $6.64 \%$ & $17.31 \%$ & $6.15 \%$ \\
\hline Batak & $41.51 \%$ & $14.41 \%$ & $15.45 \%$ & $17.54 \%$ & $7.74 \%$ & $67.01 \%$ & $72.03 \%$ & $7.52 \%$ & $6.05 \%$ & $18.58 \%$ & $10.48 \%$ \\
\hline Javanese & $29.78 \%$ & $10.14 \%$ & $13.40 \%$ & $24.93 \%$ & $12.11 \%$ & $74.09 \%$ & $71.26 \%$ & $9.68 \%$ & $7.57 \%$ & $17.19 \%$ & $6.43 \%$ \\
\hline Minangkabau & $21.38 \%$ & $8.36 \%$ & $8.36 \%$ & $15.61 \%$ & $8.57 \%$ & $53.16 \%$ & $55.20 \%$ & $10.97 \%$ & $5.20 \%$ & $21.00 \%$ & $5.85 \%$ \\
\hline
\end{tabular}


Table 3c Descriptive statistics for joint-father decision-making variables by ethnicity

\begin{tabular}{|c|c|c|c|c|c|c|c|c|c|c|c|}
\hline \multirow[t]{2}{*}{ VARIABLES } & \multicolumn{11}{|c|}{ Decisions by fathers - solely and jointly } \\
\hline & $\begin{array}{l}\text { Children's } \\
\text { clothes }\end{array}$ & $\begin{array}{l}\text { Children's } \\
\text { education }\end{array}$ & $\begin{array}{l}\text { Children's } \\
\text { health }\end{array}$ & $\begin{array}{l}\text { Monthly } \\
\text { ROSCA }\end{array}$ & $\begin{array}{l}\text { Monthly } \\
\text { savings }\end{array}$ & $\begin{array}{l}\text { Food } \\
\text { expenditure } \\
\text { at home }\end{array}$ & $\begin{array}{l}\text { Routine } \\
\text { household } \\
\text { purchases }\end{array}$ & $\begin{array}{l}\text { Giving } \\
\text { money to } \\
\text { own family }\end{array}$ & $\begin{array}{l}\text { Giving } \\
\text { money to } \\
\text { in-laws }\end{array}$ & $\begin{array}{l}\text { Giving } \\
\text { gifts }\end{array}$ & $\begin{array}{l}\text { Large, } \\
\text { expensive } \\
\text { household } \\
\text { purchases }\end{array}$ \\
\hline All ethnicities & $56.91 \%$ & $77.17 \%$ & $80.95 \%$ & $36.75 \%$ & $37.39 \%$ & $29.57 \%$ & $29.23 \%$ & $84.01 \%$ & $82.83 \%$ & $85.12 \%$ & $89.50 \%$ \\
\hline Batak & $57.55 \%$ & $77.83 \%$ & $80.90 \%$ & $31.75 \%$ & $39.10 \%$ & $32.31 \%$ & $29.95 \%$ & $89.13 \%$ & $87.23 \%$ & $81.60 \%$ & $90.78 \%$ \\
\hline Javanese & $56.44 \%$ & $79.21 \%$ & $82.31 \%$ & $45.37 \%$ & $39.01 \%$ & $26.63 \%$ & $27.06 \%$ & $84.90 \%$ & $84.44 \%$ & $85.51 \%$ & $91.40 \%$ \\
\hline Minangkabau & $67.70 \%$ & $81.07 \%$ & $83.33 \%$ & $33.13 \%$ & $38.27 \%$ & $48.97 \%$ & $46.30 \%$ & $81.07 \%$ & $73.87 \%$ & $81.65 \%$ & $89.05 \%$ \\
\hline
\end{tabular}

Table 3d Descriptive statistics for joint-mother decision-making variables by ethnicity

\begin{tabular}{|c|c|c|c|c|c|c|c|c|c|c|c|}
\hline \multirow[t]{2}{*}{ VARIABLES } & \multicolumn{11}{|c|}{ Decisions by mothers - solely and jointly } \\
\hline & $\begin{array}{l}\text { Children's } \\
\text { clothes }\end{array}$ & $\begin{array}{l}\text { Children's } \\
\text { education }\end{array}$ & $\begin{array}{l}\text { Children's } \\
\text { health }\end{array}$ & $\begin{array}{l}\text { Monthly } \\
\text { ROSCA }\end{array}$ & $\begin{array}{l}\text { Monthly } \\
\text { savings }\end{array}$ & $\begin{array}{l}\text { Food } \\
\text { expenditure } \\
\text { at home }\end{array}$ & $\begin{array}{l}\text { Routine } \\
\text { household } \\
\text { purchases }\end{array}$ & $\begin{array}{l}\text { Giving } \\
\text { money to } \\
\text { own family }\end{array}$ & $\begin{array}{l}\text { Giving } \\
\text { money to } \\
\text { in-laws }\end{array}$ & $\begin{array}{l}\text { Giving } \\
\text { gifts }\end{array}$ & $\begin{array}{l}\text { Large, } \\
\text { expensive } \\
\text { household } \\
\text { purchases }\end{array}$ \\
\hline All ethnicities & $80.57 \%$ & $80.70 \%$ & $87.09 \%$ & $53.00 \%$ & $40.09 \%$ & $90.59 \%$ & $91.19 \%$ & $85.12 \%$ & $81.97 \%$ & $94.14 \%$ & $81.57 \%$ \\
\hline Batak & $89.31 \%$ & $89.56 \%$ & $92.90 \%$ & $45.09 \%$ & $42.68 \%$ & $93.53 \%$ & $94.57 \%$ & $85.18 \%$ & $83.72 \%$ & $96.66 \%$ & $86.79 \%$ \\
\hline Javanese & $81.61 \%$ & $83.25 \%$ & $89.00 \%$ & $63.05 \%$ & $43.84 \%$ & $91.57 \%$ & $91.46 \%$ & $86.42 \%$ & $83.40 \%$ & $94.25 \%$ & $84.63 \%$ \\
\hline Minangkabau & $80.86 \%$ & $83.09 \%$ & $88.29 \%$ & $49.63 \%$ & $40.78 \%$ & $86.06 \%$ & $88.85 \%$ & $79.74 \%$ & $72.49 \%$ & $93.49 \%$ & $84.91 \%$ \\
\hline
\end{tabular}


Across all the ethnic groups we find that mothers are more likely to make savings-related decisions on their own than fathers (see Tables 3a and 3b), in particular on ROSCAs, an informal savings mechanism (Wydick, 2008).

In Indonesia, ceremonial gift giving and transfers of money within the extended family are a common occurrence (Park, 2003). As seen in Table 3, mothers are more likely to make these decisions on their own than fathers across all ethnic groups, especially amongst the matrilineal Minangkabau. Both Javanese and Minangkabau women are economically active and typically have responsibility for maintaining social relationships (Esten, 1993; Sanday, 2002; Weix, 2000; Wolf, 2000) which would explain this. While fathers are more likely to make decisions relating to large and expensive household purchases on their own for all ethnic groups, mothers make all small and routine household expenditure decisions albeit less amongst the Minangkabau. 
Decisions relating to children

Children provide a key sphere of household decision-making and Table 3 indicates that mothers from all ethnic groups are more likely to make child-related decisions on their own, with fathers least likely to make decisions relating to children's clothing. While the most common approach is joint decision-making, particularly for child health and education decisions, Batak women and Minangkabau men are more likely to make these decisions than their counterparts in the other groups.

In the next section, we will consider the extent to which these autonomy variables influence household education expenditure.

\section{Results}

As mentioned earlier, we estimate two versions of our model - the first with relative income, age and education as indirect proxies for agency and the second with the decisionmaking variables discussed above. Since relative education is time invariant and the variability in relative age is limited, we estimate the model which includes these variables as a pooled data model with time dummies rather than as a panel fixed effects model (see Table 4).

The second version of the model with decision making variables as proxies for agency is estimated as a panel fixed effects model (Tables 5 and 5a). All our estimations include the following controls: household income, asset ownership, parent's education levels, number of children in the household, parent's employment status, ethnicity and religion. The results for our control variables are not presented below to keep the size of tables manageable. 
Table 4 Household education expenditure estimation results - indirect proxies for agency

\begin{tabular}{|l|c|c|c|c|}
\hline \multirow{2}{*}{ VARIABLES } & \multicolumn{4}{|c|}{ Household education expenditure (quasi-pooled) } \\
\cline { 2 - 5 } & \multicolumn{4}{|c|}{ Model 1 } \\
\cline { 2 - 5 } & All ethnicities & Batak & Javanese & Minangkabau \\
\hline Relative income & $0.0554^{* * *}$ & $0.1399^{* *}$ & $0.0438^{* *}$ & 0.0977 \\
Relative age & {$[0.013]$} & {$[0.067]$} & {$[0.018]$} & {$[0.062]$} \\
& $0.0702^{* *}$ & 0.0517 & $0.0993^{* *}$ & $0.3036^{* *}$ \\
Relative education & {$[0.030]$} & {$[0.149]$} & {$[0.045]$} & {$[0.148]$} \\
& $0.0481^{* * *}$ & $0.1385^{*}$ & $0.0689^{* * *}$ & -0.0402 \\
Control variables included ${ }^{15}$ & {$[0.013]$} & {$[0.071]$} & {$[0.020]$} & {$[0.061]$} \\
Constant & Yes & Yes & Yes & Yes \\
& -0.0670 & -0.3747 & -0.0151 & -0.4407 \\
Observations & {$[0.058]$} & {$[0.317]$} & {$[0.084]$} & {$[0.320]$} \\
R-squared & 6,230 & 228 & 2,831 & 240 \\
Robust standard errors in brackets $* * *$ & $0.01, * * p<0.05, * p<0.1$ & 0.45 & 0.392 & 0.457 \\
\hline
\end{tabular}

We use a linear regression with time fixed effects using IFLS2 as the base

\subsection{The indirect measures of agency}

As seen in Table 4, when we consider all ethnic groups together, each of our measures of agency has a different impact on household education expenditure. When women contribute relatively more to household income, there is a $5.5 \%$ increase in household spending on education. Similarly, when women are relatively better educated, household spending on education increases by $4.8 \%$. Our results here are similar to other research which finds women's agency to be an important determinant of the use of household resources (for example Abadian, 1996; Blumberg, 1988; Hoddinott \& Haddad, 1991, 1995; Kabeer, 1997, 1999; Quisumbing, 2003; Seebens \& Sauer, 2007; Thomas, 1990, 1993).

However, when we consider each of the ethnic groups separately, we find several differences. Amongst the matrilineal Minangkabau, relative age is the most significant measure of autonomy, increasing household expenditure on education by $30.4 \%$ while

\footnotetext{
${ }^{15}$ Control variables are religion, parents' education, parents' employment, household income, ownership of assets and number of children in the household by age
} 
amongst the Batak, relative income and relative education are both significant. Household expenditure on education increases by $14.0 \%$ when Batak women earn more than their husbands and by $13.9 \%$ when they are better educated.

It is only among the Javanese that all three indirect measures of women's agency have a significant impact on household education. When Javanese women contribute relatively more to household income there is a $4.4 \%$ increase and when they are older than their spouses there is almost a $10.0 \%$ increase in education expenditure.

Our results therefore indicate that autonomy is captured differently in the different groups as Beegle et al. (2001) also found for Indonesia. These results are limited by the broad nature of these autonomy variables and by the fact that with relative education being time invariant, it is not possible to estimate the model using panel fixed effects. We have instead included a time dummy to capture macro changes and changes in norms across time. We now turn to our main model estimated with decision making as our measure of autonomy.

\subsection{The direct measures of agency}

In Tables 5and 5a, we provide a summary of the net impact of decisions made by various agents within the household on household education expenditure.

To make the tables simpler to read, we report only significant results (see Appendix for complete results). 
Table 5 Net impact of significant individual decision-making on household education expenditure!

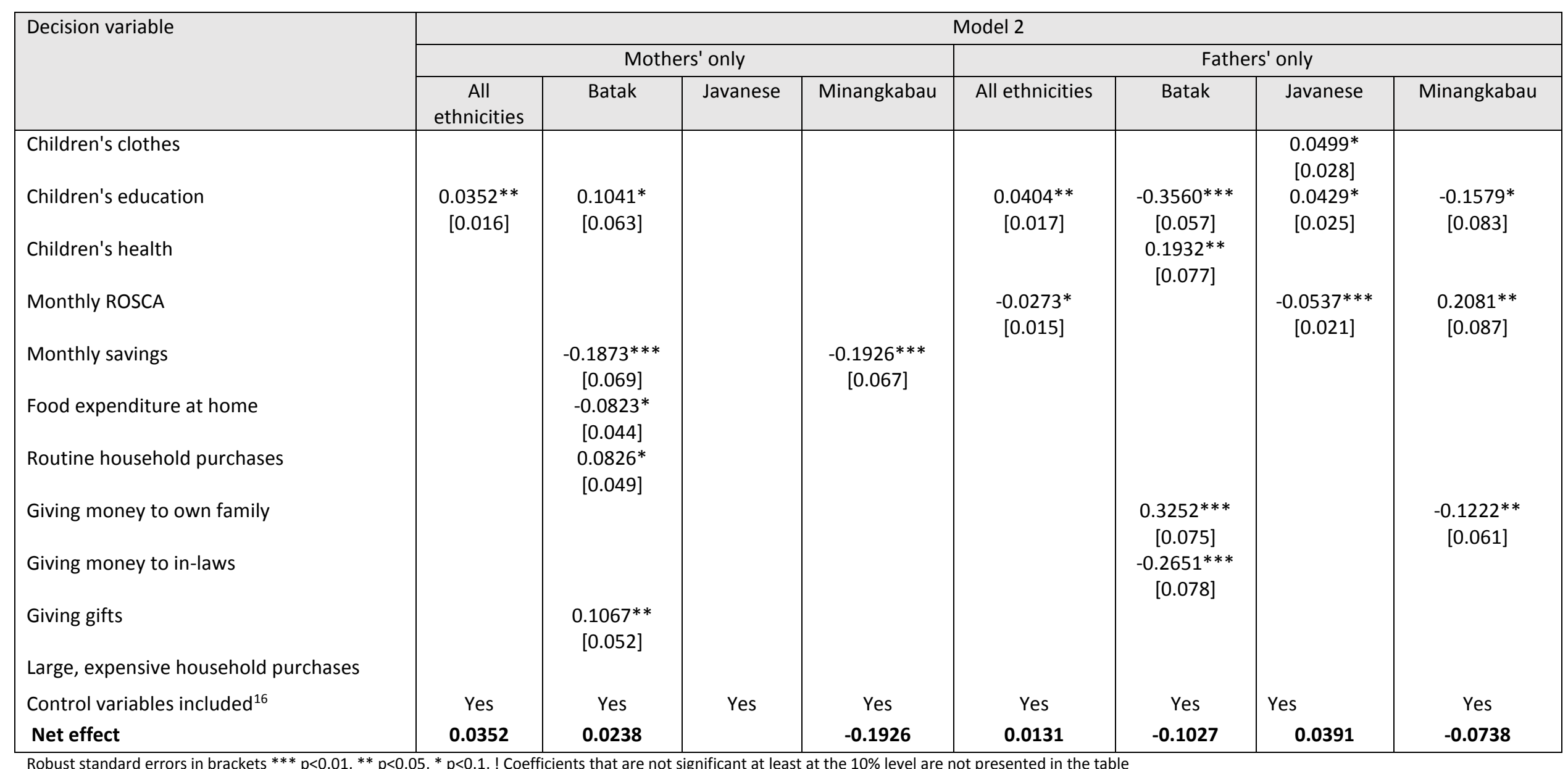

${ }^{16}$ Control variables are religion, parents' education, parents' employment, household income, ownership of assets and number of children in the household by age 
Table 5a Net impact of joint significant decision-making on household education expenditure!

\begin{tabular}{|c|c|c|c|c|c|c|c|c|}
\hline \multirow[t]{3}{*}{ Decision variable } & \multicolumn{8}{|c|}{ Model 2a } \\
\hline & \multicolumn{4}{|c|}{ Mothers' only and joint } & \multicolumn{4}{|c|}{ Fathers' only and joint } \\
\hline & All ethnicities & Batak & Javanese & Minangkabau & All ethnicities & Batak & Javanese & Minangkabau \\
\hline Children's clothes & $\begin{array}{c}0.0231^{* *} \\
{[0.011]}\end{array}$ & & & & & $\begin{array}{c}-0.1101 * * * \\
{[0.040]}\end{array}$ & & \\
\hline Children's education & $\begin{array}{c}0.1019 * * * \\
{[0.011]}\end{array}$ & & $\begin{array}{c}0.0979 * * * \\
{[0.018]}\end{array}$ & & $\begin{array}{c}0.0892 * * * \\
{[0.011]}\end{array}$ & & $\begin{array}{c}0.0804 * * * \\
{[0.018]}\end{array}$ & \\
\hline Children's health & $\begin{array}{c}-0.0306 * * \\
{[0.015]}\end{array}$ & & $\begin{array}{c}-0.0624 * * * \\
{[0.024]}\end{array}$ & & $\begin{array}{c}-0.0399 * * * \\
{[0.013]}\end{array}$ & $\begin{array}{c}0.2064 * * * \\
{[0.058]}\end{array}$ & $\begin{array}{c}-0.0408 * * \\
{[0.019]}\end{array}$ & \\
\hline Monthly ROSCA & $\begin{array}{c}-0.0150^{*} \\
{[0.008]}\end{array}$ & & & & & & & \\
\hline Monthly savings & & & $\begin{array}{c}0.0232 * * \\
{[0.011]}\end{array}$ & $\begin{array}{c}-0.1169 * * \\
{[0.054]}\end{array}$ & & $\begin{array}{c}0.0850^{*} \\
{[0.049]}\end{array}$ & & \\
\hline Food expenditure at home & & & & $\begin{array}{c}0.1982 * * * \\
{[0.073]}\end{array}$ & & $\begin{array}{c}0.1328^{* *} \\
{[0.060]}\end{array}$ & & \\
\hline Routine household purchases & & & & $\begin{array}{c}-0.1978 * * * \\
{[0.076]}\end{array}$ & & & & \\
\hline Giving money to own family & & & & & & $\begin{array}{c}0.2302 * * * \\
{[0.069]}\end{array}$ & & $\begin{array}{c}-0.1144 * * \\
{[0.057]}\end{array}$ \\
\hline Giving money to in-laws & & & & & & $\begin{array}{c}-0.1319 * * \\
{[0.065]}\end{array}$ & & $\begin{array}{c}0.1745 * * * \\
{[0.051]}\end{array}$ \\
\hline Giving gifts & $\begin{array}{l}0.0244 * \\
{[0.015]}\end{array}$ & $\begin{array}{c}0.2279 * * \\
{[0.092]}\end{array}$ & & & & & $\begin{array}{c}0.0274 * \\
{[0.015]}\end{array}$ & \\
\hline Large, expensive household purchases & & & & & & & & $\begin{array}{c}-0.1628 * * \\
{[0.067]}\end{array}$ \\
\hline Control variables included ${ }^{17}$ & Yes & Yes & Yes & Yes & Yes & Yes & Yes & Yes \\
\hline Net effect & 0.1038 & 0.2279 & 0.0587 & -0.1165 & 0.0493 & 0.4124 & 0.067 & -0.1027 \\
\hline
\end{tabular}

Robust standard errors in brackets ${ }^{* * *} p<0.01,{ }^{* *} p<0.05,{ }^{*} p<0.1$, ! Coefficients that are not significant at least at the $10 \%$ level are not presented in the table

${ }^{17}$ Control variables are religion, parents' education, parents' employment, household income, ownership of assets and number of children in the household by age 
Table 5 presents the results for individual only decision making (mother only and father only) while Table 5a includes joint decision-making (i.e. mother only and joint decision making and father only and joint decision making). We calculate the net effect by summing the significant coefficients for decisions made by mothers and by fathers alone (Table 5) or in conjunction with others (Table 5a). This gives us an overall 'net' impact of decisions made by mothers or fathers on household education expenditure.

\subsubsection{Agency of the dominant spouse}

From Table 5 we see that, in general, when the dominant spouse has sole control of decision-making, there is an overall negative impact on education expenditure. This is the case for mother-only decision making amongst the Minangkabau and father-only decision making amongst the Batak where education expenditure is $19.3 \%$ lower and $10.3 \%$ lower respectively. Our results in Table 5 therefore show that mothers' sole control over decisionmaking does not always guarantee the best outcome for household welfare.

When Minangkabau mothers make decisions, there is only one decision that has a significant impact on household expenditure on education - monthly savings. Amongst the Minangkabau, there is a $19.3 \%$ fall in total household education expenditure when mothers make monthly savings decisions. There are parallels here between the results of Minangkabau mothers' and Batak fathers' sole decision-making though in each case different decisions are significant. When Batak fathers have sole control over children's education decisions and giving money to their in-laws, there is a $35.6 \%$ and $26.5 \%$ decrease in household education expenditure respectively, offset by greater education spending 
when they make decisions relating to children's health and giving money to their own family.

Household education expenditure increases when Batak mothers make decisions about children's education while Minangkabau fathers' decision-making has a smaller negative impact on education expenditure (-7.4\%) compared to Minangkabau mothers (-19.3\%).

Amongst Javanese mothers, no decision-making variables are significant. But, when fathers make decisions about children's education, this has a positive impact on household expenditure on education only amongst the Javanese. In the other two groups, fathers' decision making in this domain has a negative impact on education expenditure, albeit less so for Minangkabau fathers.

These results indicate it might be more important to consider the issue of dominance, rather than gender alone. Outcomes are less good in communities where either men or women are dominant. In these communities, increasing the agency of the weaker spouse can be beneficial - mother only decision-making among the Batak increases education expenditure by $2.4 \%$ while father only decision making amongst the Minangkabau has a smaller negative effect. Thus, there is some evidence that a more equal distribution of power is better for household welfare. We turn now to consider the impact of joint decision-making on outcomes. 


\subsubsection{Shared agency}

Compared to mother or father-only decision-making, we find that joint decision-making by mothers and fathers with their spouses results in greater household expenditure on education.

We compare decision-making just by mothers (Table 5 , columns $2-5$ ) to decision-making by mothers and joint decision-making (Table 5a, columns $2-5$ ). When looking at all the ethnic groups together, household education expenditure is $10.4 \%$ higher when mothers are involved (either singly or jointly) in decision-making. This is higher than the $3.5 \%$ effects for mother-only decision-making in Table 5 . This is seen across all the ethnic groups. In particular, among the Batak where mother and joint-decision-making increases education expenditure by $22.8 \%$ (Table 5 a) compared to $2.4 \%$ (Table 5 ) when decisions are made solely by mothers and $-10.3 \%$ when decisions are made by fathers only (Table 5 ).

This is also the case when comparing father-only decision making (Table 5) with father and joint decision-making (Table 5a). Here, the largest impact is seen amongst the Batak. When fathers make decisions alone, total household education expenditure decreases by $10.3 \%$. However, when decisions are made either by fathers alone or by fathers jointly with mothers, total household education expenditure increases by $41.2 \%$.

These results confirm that it might not be the gender of the parent that is most important for household welfare outcomes but rather his or her relative power. In particular, joint decision-making of this kind is most beneficial for household expenditure on education amongst the Batak. It is least impactful amongst the Minangkabau, where it continues to lead to decreases in education expenditure. However, even within this group when mothers 
make joint decisions, the magnitude of the reduction in expenditure decreases from $-19.3 \%$ to $-11.7 \%$. This is true also for Javanese where joint decision-making increases education expenditure significantly.

\section{Conclusion}

In this paper, we analyzed the impact of women's agency on household expenditure on education in Indonesia. We were especially interested in whether it was women's agency per se or increased agency for the less dominant spouse in a household that would positively affect household education expenditure.

Indonesia was a good case in which to study this because gender norms vary across ethnicities which allowed us to study this issue across matrilineal and patrilineal groups. With men being relatively less dominant in the former and women in the latter, an analysis spread across these groups allowed us to consider the role of gender compared to dominance in determining household welfare outcomes. We tested the impact of agency on household expenditure on education using three rounds of the IFLS dataset.

We used two types of agency measures - those which are broad proxy indicators (relative income of the spouses, relative education and relative age) and more detailed decision making variables. We found that while the former allowed us to broadly conclude on whether mother's autonomy influences household expenditure on education, it did not let us identify the precise sphere in which such autonomy is effective. It also did not let us consider the relative role of the less dominant spouse (mothers amongst the Batak and fathers amongst the Minangkabau). The decision-making variables, on the other hand, allowed us to do this and as such were a significant methodological improvement on the 
indirect proxies. These decision-making variables also allowed us to capture changes in decision making norms over time and thereby allowed us to capture the effect of these changes.

Our results indicate that household welfare is increased not by women's agency alone but by greater co-operation between the spouses. In fact, when the dominant spouse has sole control of decision-making, there is a decrease in education expenditure. This is true both for mothers who are dominant (in the Minangkabau group) as well as for fathers (amongst the Batak). Our results suggest a more nuanced approach to empowerment is needed - in particular, it is important to consider the issue of dominance rather than wholly focusing on gender. These results are similar to (Basu \& Ray, 2002) findings that there would be more child labor in households with greater levels of gender inequality. When the benefits of child work are spread across the parents and there is parental congruence in goals, then we can expect an improvement in household welfare. Cooperation also reduces selfishness as the communication and information sharing needed to make decisions together reduces the opportunities for selfish behavior thereby affecting how household resources are used.

Our results might relate to the fact that Indonesia is a middle-income country with relatively equitable gender relations. While it increases household welfare to empower women in poor patriarchal and patrilineal societies, this is largely because women are the less empowered partners in these communities. Such empowerment therefore leads to more equitable household relations. On the other hand, in communities that are matrilineal or where more equal gender relations are the norm, further increasing mother's power would not necessarily be beneficial. In these communities, it would be important to work towards greater equality within the household. 
Appendix 1

Table 6 Full estimation results of household education expenditure for Model 2a

\begin{tabular}{|c|c|c|c|c|c|c|c|c|}
\hline \multirow[b]{2}{*}{ VARIABLES } & \multicolumn{4}{|c|}{ Father only } & \multicolumn{4}{|c|}{ Mother only } \\
\hline & $\begin{array}{c}\text { All } \\
\text { ethnicities }\end{array}$ & Batak & Javanese & Minangkabau & $\begin{array}{c}\text { All } \\
\text { ethnicities }\end{array}$ & Batak & Javanese & Minangkabau \\
\hline $\begin{array}{l}\text { Christian: Father } \\
\text { Base: Islam }\end{array}$ & $\begin{array}{l}-0.0411 \\
{[0.059]}\end{array}$ & $\begin{array}{l}0.1217 \\
{[0.219]}\end{array}$ & $\begin{array}{c}0.1531^{* *} \\
{[0.069]}\end{array}$ & & $\begin{array}{l}-0.0334 \\
{[0.058]}\end{array}$ & & $\begin{array}{l}0.0857 \\
{[0.075]}\end{array}$ & \\
\hline $\begin{array}{l}\text { Other religion: Father } \\
\text { Base: Islam }\end{array}$ & $\begin{array}{l}-0.1312 \\
{[0.095]}\end{array}$ & & $\begin{array}{c}0.2208^{* *} \\
{[0.088]}\end{array}$ & & $\begin{array}{l}-0.0932 \\
{[0.085]}\end{array}$ & & $\begin{array}{c}0.2280^{* * *} \\
{[0.087]}\end{array}$ & \\
\hline $\begin{array}{l}\text { Christian: Mother } \\
\text { Base: Islam }\end{array}$ & $\begin{array}{l}-0.0105 \\
{[0.069]}\end{array}$ & $\begin{array}{l}0.0224 \\
{[0.069]}\end{array}$ & $\begin{array}{c}-0.2049 * \\
{[0.106]}\end{array}$ & & $\begin{array}{l}-0.0437 \\
{[0.069]}\end{array}$ & $\begin{array}{l}-0.0506 \\
{[0.077]}\end{array}$ & $\begin{array}{c}-0.2424^{* *} \\
{[0.120]}\end{array}$ & \\
\hline $\begin{array}{l}\text { Other religion: Mother } \\
\text { Base: Islam }\end{array}$ & $\begin{array}{l}0.0142 \\
{[0.084]}\end{array}$ & & $\begin{array}{c}-0.3523^{* * *} \\
{[0.032]}\end{array}$ & $\begin{array}{l}-0.0945 \\
{[0.129]}\end{array}$ & $\begin{array}{l}-0.0097 \\
{[0.084]}\end{array}$ & & $\begin{array}{c}-0.3483^{* * *} \\
{[0.035]}\end{array}$ & $\begin{array}{l}-0.1792 \\
{[0.137]}\end{array}$ \\
\hline Number of children: boys primary age $(\mathrm{HH})$ & $\begin{array}{c}0.1206 * * * \\
{[0.006]}\end{array}$ & $\begin{array}{l}0.0375 \\
{[0.042]}\end{array}$ & $\begin{array}{c}0.1303^{* * *} \\
{[0.010]}\end{array}$ & $\begin{array}{c}0.1059 * * * \\
{[0.026]}\end{array}$ & $\begin{array}{c}0.1232^{* * *} \\
{[0.006]}\end{array}$ & $\begin{array}{l}0.0257 \\
{[0.032]}\end{array}$ & $\begin{array}{c}0.1377^{* * *} \\
{[0.010]}\end{array}$ & $\begin{array}{c}0.1068 * * * \\
{[0.027]}\end{array}$ \\
\hline Number of children: girls primary age $(\mathrm{HH})$ & $\begin{array}{c}0.1178^{* * *} \\
{[0.007]}\end{array}$ & $\begin{array}{l}0.0354 \\
{[0.032]}\end{array}$ & $\begin{array}{c}0.1213^{* * *} \\
{[0.010]}\end{array}$ & $\begin{array}{c}0.0906 * * \\
{[0.041]}\end{array}$ & $\begin{array}{c}0.1210^{* * *} \\
{[0.006]}\end{array}$ & $\begin{array}{l}0.0314 \\
{[0.032]}\end{array}$ & $\begin{array}{c}0.1251^{* * *} \\
{[0.010]}\end{array}$ & $\begin{array}{c}0.0956 * * * \\
{[0.035]}\end{array}$ \\
\hline $\begin{array}{l}\text { Number of children: boys junior high age } \\
(\mathrm{HH})\end{array}$ & $\begin{array}{c}0.1050^{* * *} \\
{[0.008]}\end{array}$ & $\begin{array}{l}0.0388 \\
{[0.045]}\end{array}$ & $\begin{array}{c}0.1046^{* * *} \\
{[0.013]}\end{array}$ & $\begin{array}{c}0.1747^{* * *} \\
{[0.047]}\end{array}$ & $\begin{array}{c}0.1042^{* * *} \\
{[0.008]}\end{array}$ & $\begin{array}{c}0.0643 * \\
{[0.037]}\end{array}$ & $\begin{array}{c}0.1091^{* * *} \\
{[0.013]}\end{array}$ & $\begin{array}{c}0.1441 * * * \\
\quad[0.043]\end{array}$ \\
\hline $\begin{array}{l}\text { Number of children: girls junior high age } \\
(\mathrm{HH})\end{array}$ & $\begin{array}{c}0.1089 * * * \\
{[0.009]}\end{array}$ & $\begin{array}{l}0.0404 \\
{[0.044]}\end{array}$ & $\begin{array}{c}0.1391 * * * \\
{[0.013]}\end{array}$ & $\begin{array}{c}0.1205^{* *} \\
{[0.060]}\end{array}$ & $\begin{array}{c}0.1105^{* * *} \\
{[0.008]}\end{array}$ & $\begin{array}{c}0.1013 * * \\
{[0.041]}\end{array}$ & $\begin{array}{c}0.1361 * * * \\
{[0.013]}\end{array}$ & $\begin{array}{c}0.1216^{* *} \\
{[0.049]}\end{array}$ \\
\hline $\begin{array}{l}\text { Number of children: boys senior high age } \\
(\mathrm{HH})\end{array}$ & $\begin{array}{c}0.0865^{* * *} \\
{[0.009]}\end{array}$ & $\begin{array}{c}0.1160 * * \\
{[0.056]}\end{array}$ & $\begin{array}{c}0.0988 * * * \\
{[0.014]}\end{array}$ & $\begin{array}{l}0.0971 * \\
{[0.052]}\end{array}$ & $\begin{array}{c}0.0826 * * * \\
{[0.009]}\end{array}$ & $\begin{array}{l}0.0359 \\
{[0.045]}\end{array}$ & $\begin{array}{c}0.0991 * * * \\
{[0.013]}\end{array}$ & $\begin{array}{l}0.0801 \\
{[0.060]}\end{array}$ \\
\hline
\end{tabular}




Number of children: girls senior high age
(HH)
Number of children: boys tertiary
education age (HH)
Number of children: girls tertiary
education age (HH)
Wife's education: primary
Base: no education
Wife's education: junior high
Base: no education
Wife's education: senior high
Base: no education
Wife's education: tertiary
Base: no education
Husband's education: junior high
Base: no education or primary only
Husband's education: senior high
Base: no education or primary only
Husband's education: tertiary
Base: no education or primary only
Employed: husband
Employed: wife
Ownership of house

\begin{tabular}{|c|c|c|c|c|c|c|c|}
\hline $0.0780 * * *$ & 0.0407 & $0.0808^{* * *}$ & 0.0618 & $0.0769 * * *$ & $0.1032^{* *}$ & $0.0828^{* * *}$ & 0.0257 \\
\hline$[0.010]$ & [0.043] & [0.015] & [0.051] & [0.010] & [0.041] & [0.015] & [0.054] \\
\hline $0.0419 * * *$ & $0.0936^{*}$ & $0.0356 * *$ & $0.1230 * *$ & $0.0402 * * *$ & $0.1106^{* *}$ & $0.0355^{* *}$ & 0.0817 \\
\hline [0.010] & {$[0.048]$} & [0.015] & [0.049] & [0.010] & {$[0.043]$} & [0.015] & [0.055] \\
\hline $0.0425 * * *$ & 0.0801 & $0.0361 * *$ & 0.0880 & $0.0382 * * *$ & $0.0820 *$ & 0.0263 & 0.0867 \\
\hline [0.011] & [0.050] & [0.017] & [0.070] & [0.011] & [0.045] & [0.016] & {$[0.076]$} \\
\hline 0.0132 & 0.0555 & 0.0045 & 0.0722 & 0.0057 & $0.2475 *$ & -0.0068 & 0.1149 \\
\hline [0.020] & [0.096] & [0.028] & [0.077] & [0.020] & [0.127] & [0.028] & [0.084] \\
\hline 0.0184 & 0.1243 & -0.0107 & -0.0527 & 0.0076 & 0.2449 & -0.0389 & -0.0094 \\
\hline [0.032] & [0.128] & [0.048] & [0.139] & [0.031] & [0.160] & [0.048] & [0.120] \\
\hline-0.0131 & 0.2070 & -0.1321 & 0.1650 & -0.0168 & 0.2391 & -0.1138 & 0.1906 \\
\hline [0.044] & [0.209] & [0.080] & [0.132] & [0.041] & [0.174] & {$[0.075]$} & [0.133] \\
\hline 0.0113 & 0.3782 & $-0.2415^{* *}$ & 0.2258 & 0.0085 & 0.3051 & $-0.1965^{* *}$ & 0.1605 \\
\hline [0.057] & [0.250] & [0.097] & [0.229] & [0.053] & [0.203] & [0.094] & [0.230] \\
\hline 0.0337 & $0.1675^{* * *}$ & 0.0377 & -0.0205 & 0.0226 & 0.0761 & 0.0207 & -0.0437 \\
\hline [0.021] & [0.063] & [0.032] & [0.085] & [0.020] & [0.058] & [0.033] & [0.069] \\
\hline 0.0299 & $0.3084^{* * *}$ & $0.0929 *$ & 0.1012 & 0.0170 & 0.0751 & 0.0573 & 0.0413 \\
\hline [0.030] & [0.117] & {$[0.051]$} & [0.109] & [0.029] & [0.130] & [0.051] & {$[0.087]$} \\
\hline $0.0861 * *$ & $0.4497 * * *$ & $0.1858^{* *}$ & 0.1764 & $0.0657^{*}$ & $0.3782 * *$ & $0.1463 *$ & 0.1425 \\
\hline$[0.041]$ & [0.164] & {$[0.078]$} & [0.139] & [0.039] & [0.188] & {$[0.076]$} & [0.149] \\
\hline $0.0440 * * *$ & $0.1600 * *$ & $0.0403 * *$ & 0.1020 & 0.0083 & 0.0710 & 0.0077 & 0.0254 \\
\hline [0.014] & [0.080] & {$[0.020]$} & [0.087] & [0.013] & {$[0.087]$} & {$[0.020]$} & [0.082] \\
\hline 0.0008 & -0.0673 & 0.0189 & $-0.0831 *$ & 0.0016 & $-0.0737^{*}$ & 0.0161 & -0.0526 \\
\hline [0.008] & [0.059] & [0.013] & [0.043] & [0.008] & [0.042] & {$[0.012]$} & [0.045] \\
\hline $0.0307 * *$ & 0.0309 & $0.0381 * *$ & -0.0476 & $0.0235^{* *}$ & 0.0432 & $0.0342^{*}$ & -0.0532 \\
\hline [0.012] & [0.081] & [0.019] & [0.052] & [0.011] & [0.061] & {$[0.018]$} & [0.050] \\
\hline
\end{tabular}




\begin{tabular}{|c|c|c|c|c|c|c|c|c|}
\hline $\begin{array}{l}\text { Inflation adjusted log of total household } \\
\text { income }\end{array}$ & $-0.0236 * * *$ & [0.019] & $-0.0402 * * *$ & $-0.0422 * *$ & $-0.0232 * * *$ & {$[0.017]$} & $-0.0407 * * *$ & $-0.0402 * *$ \\
\hline \multirow[t]{2}{*}{ Fathers-only decision: Children's clothes } & 0.0080 & -0.0382 & $0.0499 *$ & 0.0131 & 0.0008 & -0.0562 & -0.0118 & 0.0335 \\
\hline & [0.018] & [0.061] & {$[0.028]$} & {$[0.071]$} & [0.009] & {$[0.043]$} & [0.014] & [0.067] \\
\hline \multirow[t]{2}{*}{ Fathers-only decision: Children's education } & $0.0404 * *$ & $-0.3560 * * *$ & $0.0429 *$ & $-0.1579 *$ & $0.0352 * *$ & $0.1041^{*}$ & 0.0260 & -0.0494 \\
\hline & [0.017] & [0.057] & {$[0.025]$} & [0.083] & {$[0.016]$} & {$[0.063]$} & {$[0.024]$} & {$[0.103]$} \\
\hline \multirow[t]{2}{*}{ Fathers-only decision: Children's health } & 0.0079 & $0.1932 * *$ & -0.0096 & 0.0120 & -0.0130 & -0.0176 & -0.0219 & 0.0606 \\
\hline & {$[0.018]$} & [0.077] & [0.027] & {$[0.090]$} & {$[0.015]$} & {$[0.050]$} & {$[0.022]$} & {$[0.102]$} \\
\hline \multirow[t]{2}{*}{ Fathers-only decision: monthly ROSCA } & $-0.0273^{*}$ & -0.0962 & $-0.0537 * * *$ & $0.2081 * *$ & 0.0023 & 0.0150 & -0.0040 & 0.0793 \\
\hline & [0.015] & {$[0.111]$} & [0.021] & [0.087] & {$[0.009]$} & [0.048] & {$[0.013]$} & {$[0.052]$} \\
\hline \multirow[t]{2}{*}{ Fathers-only decision: monthly savings } & -0.0050 & 0.0450 & 0.0190 & -0.1122 & -0.0102 & $-0.1873 * * *$ & 0.0107 & $-0.1926 * * *$ \\
\hline & {$[0.014]$} & {$[0.098]$} & [0.021] & {$[0.081]$} & {$[0.012]$} & [0.069] & {$[0.016]$} & [0.067] \\
\hline \multirow{2}{*}{$\begin{array}{l}\text { Fathers-only decision: food expenditure at } \\
\text { home }\end{array}$} & -0.0105 & -0.1250 & 0.0076 & -0.0293 & -0.0002 & $-0.0823^{*}$ & 0.0027 & 0.0478 \\
\hline & [0.015] & [0.143] & [0.023] & [0.062] & {$[0.010]$} & [0.044] & [0.015] & [0.044] \\
\hline \multirow{2}{*}{$\begin{array}{l}\text { Fathers-only decision: routine household } \\
\text { purchases }\end{array}$} & -0.0144 & 0.1004 & -0.0304 & 0.0746 & 0.0014 & $0.0826^{*}$ & 0.0031 & -0.0508 \\
\hline & {$[0.017]$} & {$[0.111]$} & {$[0.025]$} & {$[0.074]$} & {$[0.010]$} & {$[0.049]$} & {$[0.014]$} & [0.049] \\
\hline \multirow{2}{*}{$\begin{array}{l}\text { Fathers-only decision: giving money to } \\
\text { own family }\end{array}$} & -0.0156 & $0.3252^{* * *}$ & -0.0144 & $-0.1222 * *$ & -0.0005 & -0.0508 & -0.0144 & 0.0421 \\
\hline & {$[0.014]$} & [0.075] & {$[0.022]$} & {$[0.061]$} & {$[0.015]$} & {$[0.090]$} & {$[0.022]$} & {$[0.072]$} \\
\hline \multirow{2}{*}{$\begin{array}{l}\text { Fathers-only decision: giving money to in- } \\
\text { laws }\end{array}$} & 0.0028 & $-0.2651 * * *$ & 0.0027 & 0.0973 & -0.0093 & 0.0134 & 0.0196 & 0.1334 \\
\hline & {$[0.017]$} & {$[0.078]$} & {$[0.025]$} & [0.064] & {$[0.016]$} & [0.095] & [0.023] & [0.087] \\
\hline \multirow[t]{2}{*}{ Fathers-only decision: giving gifts } & 0.0078 & 0.1198 & 0.0032 & 0.0308 & 0.0000 & $0.1067 * *$ & -0.0174 & -0.0079 \\
\hline & {$[0.014]$} & {$[0.076]$} & {$[0.020]$} & [0.082] & {$[0.010]$} & {$[0.052]$} & [0.014] & {$[0.042]$} \\
\hline \multirow{2}{*}{$\begin{array}{l}\text { Fathers-only decision: large, expensive } \\
\text { household purchases }\end{array}$} & 0.0039 & 0.0075 & -0.0133 & 0.0226 & -0.0010 & -0.0658 & 0.0123 & -0.0521 \\
\hline & {$[0.011]$} & [0.059] & {$[0.016]$} & {$[0.056]$} & {$[0.015]$} & {$[0.060]$} & {$[0.021]$} & [0.095] \\
\hline Disagreement in answers to all decisions & $-0.0020 * * *$ & -0.0056 & $-0.0017^{*}$ & 0.0014 & -0.0002 & 0.0006 & -0.0002 & 0.0010 \\
\hline
\end{tabular}




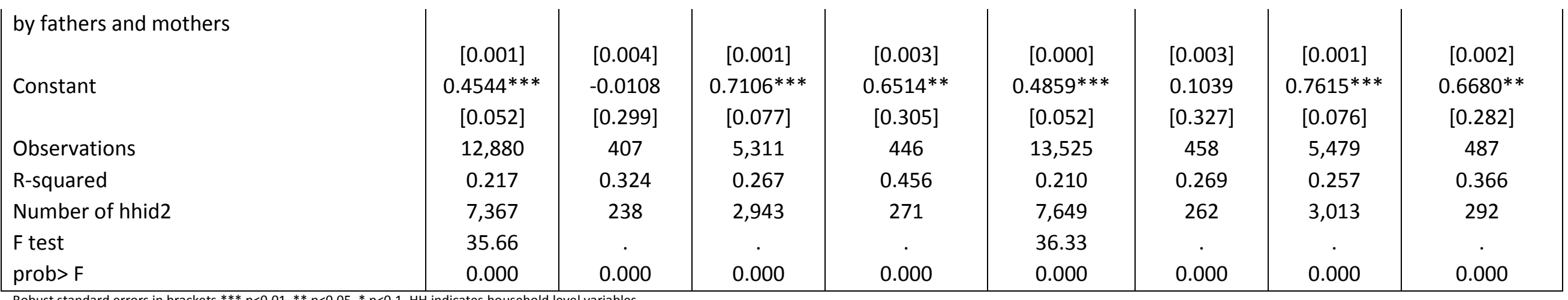

Robust standard errors in brackets ${ }^{* * *} \mathrm{p}<0.01,{ }^{* *} \mathrm{p}<0.05,{ }^{*} \mathrm{p}<0.1, \mathrm{HH}$ indicates household level variables 
Table 7 Full estimation results of household education expenditure for Model $2 \mathrm{~b}$

\begin{tabular}{|c|c|c|c|c|c|c|c|c|}
\hline \multirow[b]{2}{*}{ VARIABLES } & \multicolumn{4}{|c|}{ Father only and joint } & \multicolumn{4}{|c|}{ Mother only and joint } \\
\hline & $\begin{array}{c}\text { All } \\
\text { ethnicities }\end{array}$ & Batak & Javanese & Minangkabau & $\begin{array}{c}\text { All } \\
\text { ethnicities }\end{array}$ & Batak & Javanese & Minangkabau \\
\hline $\begin{array}{l}\text { Christian: Father } \\
\text { Base: Islam }\end{array}$ & $\begin{array}{l}-0.0383 \\
{[0.058]}\end{array}$ & $\begin{array}{l}0.1269 \\
{[0.204]}\end{array}$ & $\begin{array}{c}0.1359^{* *} \\
{[0.067]}\end{array}$ & & $\begin{array}{l}-0.0192 \\
{[0.059]}\end{array}$ & & $\begin{array}{l}0.0921 \\
{[0.075]}\end{array}$ & \\
\hline $\begin{array}{l}\text { Other religion: Father } \\
\text { Base: Islam }\end{array}$ & $\begin{array}{l}-0.1203 \\
{[0.095]}\end{array}$ & & $\begin{array}{c}0.1832^{* * *} \\
{[0.070]}\end{array}$ & & $\begin{array}{l}-0.0864 \\
{[0.090]}\end{array}$ & & $\begin{array}{c}0.2148 * * * \\
{[0.080]}\end{array}$ & \\
\hline $\begin{array}{l}\text { Christian: Mother } \\
\text { Base: Islam }\end{array}$ & $\begin{array}{l}-0.0235 \\
{[0.069]}\end{array}$ & $\begin{array}{c}0.1463^{*} \\
{[0.083]}\end{array}$ & $\begin{array}{c}-0.2159 * * \\
{[0.105]}\end{array}$ & & $\begin{array}{l}-0.0514 \\
{[0.068]}\end{array}$ & $\begin{array}{l}-0.0287 \\
{[0.063]}\end{array}$ & $\begin{array}{c}-0.2446 * * \\
{[0.113]}\end{array}$ & \\
\hline $\begin{array}{l}\text { Other religion: Mother } \\
\text { Base: Islam }\end{array}$ & $\begin{array}{l}0.0096 \\
{[0.086]}\end{array}$ & & $\begin{array}{c}-0.2880 * * * \\
{[0.040]}\end{array}$ & $\begin{array}{c}-0.2833^{* *} \\
{[0.126]}\end{array}$ & $\begin{array}{l}-0.0237 \\
{[0.082]}\end{array}$ & & $\begin{array}{c}-0.3070 * * * \\
{[0.037]}\end{array}$ & $\begin{array}{l}-0.2018 \\
{[0.147]}\end{array}$ \\
\hline $\begin{array}{l}\text { Number of children: boys primary age } \\
(\mathrm{HH})\end{array}$ & $\begin{array}{c}0.1149 * * * \\
{[0.006]}\end{array}$ & $\begin{array}{l}0.0482 \\
{[0.035]}\end{array}$ & $\begin{array}{c}0.1265^{* * *} \\
{[0.010]}\end{array}$ & $\begin{array}{c}0.1279 * * * \\
{[0.025]}\end{array}$ & $\begin{array}{c}0.1155^{* * *} \\
{[0.006]}\end{array}$ & $\begin{array}{l}0.0154 \\
{[0.035]}\end{array}$ & $\begin{array}{c}0.1320^{* * *} \\
{[0.010]}\end{array}$ & $\begin{array}{c}0.1198^{* * *} \\
{[0.027]}\end{array}$ \\
\hline $\begin{array}{l}\text { Number of children: girls primary age } \\
\text { (HH) }\end{array}$ & $\begin{array}{c}0.1126 * * * \\
{[0.007]}\end{array}$ & $\begin{array}{l}0.0343 \\
{[0.030]}\end{array}$ & $\begin{array}{c}0.1189 * * * \\
{[0.010]}\end{array}$ & $\begin{array}{c}0.0975^{* *} \\
{[0.038]}\end{array}$ & $\begin{array}{c}0.1129 * * * \\
{[0.006]}\end{array}$ & $\begin{array}{l}0.0162 \\
{[0.027]}\end{array}$ & $\begin{array}{c}0.1186^{* * *} \\
{[0.010]}\end{array}$ & $\begin{array}{c}0.0738^{* *} \\
{[0.033]}\end{array}$ \\
\hline $\begin{array}{l}\text { Number of children: boys junior high } \\
\text { age }(\mathrm{HH})\end{array}$ & $\begin{array}{c}0.1049 * * * \\
{[0.008]}\end{array}$ & $\begin{array}{l}0.0608 \\
{[0.043]}\end{array}$ & $\begin{array}{c}0.1055^{* * *} \\
{[0.013]}\end{array}$ & $\begin{array}{c}0.1632^{* * *} \\
{[0.051]}\end{array}$ & $\begin{array}{c}0.1034^{* * *} \\
{[0.008]}\end{array}$ & $\begin{array}{l}0.0410 \\
{[0.039]}\end{array}$ & $\begin{array}{c}0.1124 * * * \\
{[0.013]}\end{array}$ & $\begin{array}{c}0.1303^{* * *} \\
{[0.043]}\end{array}$ \\
\hline $\begin{array}{l}\text { Number of children: girls junior high } \\
\text { age }(\mathrm{HH})\end{array}$ & $\begin{array}{c}0.1087^{* * *} \\
{[0.009]}\end{array}$ & $\begin{array}{l}0.0297 \\
{[0.041]}\end{array}$ & $\begin{array}{c}0.1393^{* * *} \\
{[0.013]}\end{array}$ & $\begin{array}{c}0.1368 * * \\
{[0.058]}\end{array}$ & $\begin{array}{c}0.1092^{* * *} \\
{[0.008]}\end{array}$ & $\begin{array}{c}0.1168 * * * \\
{[0.039]}\end{array}$ & $\begin{array}{c}0.1320 * * * \\
{[0.013]}\end{array}$ & $\begin{array}{c}0.0900 * \\
{[0.047]}\end{array}$ \\
\hline $\begin{array}{l}\text { Number of children: boys senior high } \\
\text { age }(\mathrm{HH})\end{array}$ & $\begin{array}{c}0.0851^{* * *} \\
{[0.009]}\end{array}$ & $\begin{array}{c}0.1197 * * \\
{[0.051]}\end{array}$ & $\begin{array}{c}0.0980 * * * \\
{[0.014]}\end{array}$ & $\begin{array}{l}0.1071 * \\
{[0.055]}\end{array}$ & $\begin{array}{c}0.0819 * * * \\
{[0.009]}\end{array}$ & $\begin{array}{l}0.0443 \\
{[0.046]}\end{array}$ & $\begin{array}{c}0.0986 * * * \\
{[0.013]}\end{array}$ & $\begin{array}{l}0.0720 \\
{[0.056]}\end{array}$ \\
\hline Number of children: girls senior high & $0.0764^{* * *}$ & 0.0279 & $0.0823^{* * *}$ & $0.0851^{*}$ & $0.0750 * * *$ & $0.1025^{* *}$ & $0.0809 * * *$ & 0.0283 \\
\hline
\end{tabular}




age (HH)
Number of children: boys tertiary
education age (HH)
Number of children: girls tertiary
education age (HH)
Wife's education: primary
Base: no education
Wife's education: junior high
Base: no education
Wife's education: senior high
Base: no education
Wife's education: tertiary
Base: no education
Husband's education: junior high
Base: no education or primary only
Husband's education: senior high
Base: no education or primary only
Husband's education: tertiary
Base: no education or primary only
Employed: husband

\begin{tabular}{|c|c|c|c|c|c|c|c|}
\hline [0.010] & [0.042] & [0.014] & [0.049] & [0.010] & [0.044] & [0.014] & {$[0.052]$} \\
\hline $0.0406 * * *$ & $0.0967 *$ & $0.0349 * *$ & $0.1175^{* *}$ & $0.0396 * * *$ & $0.0969 * *$ & $0.0388 * *$ & $0.1072 *$ \\
\hline$[0.010]$ & [0.051] & [0.015] & {$[0.056]$} & [0.010] & [0.047] & [0.015] & {$[0.056]$} \\
\hline $0.0426 * * *$ & 0.0585 & $0.0392 * *$ & 0.0824 & $0.0388^{* * *}$ & 0.0576 & 0.0253 & $0.1103^{*}$ \\
\hline [0.011] & [0.049] & [0.016] & [0.066] & [0.011] & {$[0.052]$} & {$[0.016]$} & {$[0.065]$} \\
\hline 0.0189 & -0.0551 & 0.0131 & $0.1641^{* *}$ & 0.0111 & $0.3292 * * *$ & -0.0064 & $0.1170^{*}$ \\
\hline$[0.020]$ & [0.081] & [0.028] & [0.077] & {$[0.020]$} & [0.107] & [0.028] & {$[0.070]$} \\
\hline 0.0227 & -0.1441 & -0.0077 & 0.0571 & 0.0152 & $0.3420 * *$ & -0.0284 & -0.0138 \\
\hline [0.031] & [0.140] & [0.048] & [0.134] & [0.031] & [0.152] & [0.048] & [0.087] \\
\hline-0.0067 & -0.1165 & -0.1320 & 0.2175 & -0.0129 & $0.3701^{* *}$ & -0.1018 & 0.1667 \\
\hline [0.044] & [0.188] & {$[0.080]$} & {$[0.142]$} & {$[0.040]$} & [0.153] & {$[0.075]$} & [0.107] \\
\hline 0.0165 & 0.1211 & $-0.2392 * *$ & 0.3246 & 0.0139 & $0.4875^{* * *}$ & $-0.1798^{*}$ & 0.1685 \\
\hline [0.058] & [0.237] & [0.098] & {$[0.228]$} & [0.053] & [0.186] & [0.095] & [0.191] \\
\hline 0.0296 & $0.1432 * *$ & 0.0416 & -0.0149 & 0.0175 & 0.1036 & 0.0220 & -0.0413 \\
\hline$[0.021]$ & [0.072] & [0.032] & [0.087] & [0.020] & [0.068] & [0.032] & [0.065] \\
\hline 0.0264 & $0.2497 * *$ & $0.0988^{*}$ & 0.0626 & 0.0115 & 0.0856 & 0.0603 & 0.0392 \\
\hline [0.030] & [0.103] & [0.051] & [0.108] & [0.028] & [0.120] & [0.049] & [0.082] \\
\hline $0.0781 *$ & $0.5404 * * *$ & $0.1883^{* *}$ & 0.1815 & 0.0544 & $0.3479 * *$ & $0.1477^{*}$ & 0.1664 \\
\hline [0.041] & [0.159] & [0.078] & [0.158] & [0.038] & [0.169] & {$[0.076]$} & [0.149] \\
\hline $0.0453^{* * *}$ & 0.0690 & $0.0391 *$ & 0.1269 & 0.0087 & 0.0270 & 0.0048 & 0.0178 \\
\hline [0.014] & [0.079] & [0.021] & [0.095] & [0.013] & [0.085] & [0.019] & [0.078] \\
\hline 0.0026 & -0.0778 & $0.0224 *$ & $-0.0862 * *$ & 0.0037 & $-0.0810^{*}$ & 0.0188 & -0.0637 \\
\hline [0.008] & {$[0.056]$} & [0.012] & [0.041] & [0.008] & [0.044] & {$[0.012]$} & [0.044] \\
\hline $0.0267 * *$ & 0.0382 & $0.0374 * *$ & -0.0739 & 0.0178 & 0.0449 & $0.0324 *$ & -0.0458 \\
\hline [0.012] & {$[0.076]$} & [0.019] & [0.049] & [0.011] & {$[0.061]$} & [0.018] & [0.045] \\
\hline$-0.0260 * * *$ & -0.0270 & $-0.0433 * * *$ & $-0.0416^{* *}$ & $-0.0266 * * *$ & -0.0243 & $-0.0427^{* * *}$ & $-0.0401 * *$ \\
\hline
\end{tabular}




household income
Fathers-only decision: Children's
clothes
Fathers-only decision: Children's
education
Fathers-only decision: Children's health
Fathers-only decision: monthly ROSCA
Fathers-only decision: monthly savings
Fathers-only decision: food expenditure
at home
Fathers-only decision: routine
household purchases
Fathers-only decision: giving money to
own family
Fathers-only decision: giving money to
in-laws
Fathers-only decision: giving gifts
Fathers-only decision: large, expensive
household purchases

\begin{tabular}{|c|c|c|}
\hline [0.003] & {$[0.021]$} & [0.004] \\
\hline 0.0002 & $-0.1101 * * *$ & 0.0111 \\
\hline$[0.008]$ & [0.040] & [0.012] \\
\hline $0.0892 * * *$ & -0.0591 & $0.0804 * * *$ \\
\hline [0.011] & [0.058] & [0.018] \\
\hline$-0.0399 * * *$ & $0.2064 * * *$ & $-0.0408 * *$ \\
\hline$[0.013]$ & {$[0.058]$} & {$[0.019]$} \\
\hline-0.0016 & -0.0667 & -0.0040 \\
\hline [0.008] & [0.063] & {$[0.012]$} \\
\hline 0.0053 & $0.0850 *$ & 0.0120 \\
\hline [0.008] & [0.049] & [0.012] \\
\hline-0.0007 & $0.1328 * *$ & -0.0102 \\
\hline [0.010] & {$[0.060]$} & {$[0.015]$} \\
\hline-0.0059 & -0.1033 & -0.0119 \\
\hline [0.010] & [0.065] & [0.015] \\
\hline-0.0137 & $0.2302 * * *$ & 0.0073 \\
\hline$[0.013]$ & [0.069] & {$[0.019]$} \\
\hline-0.0019 & $-0.1319 * *$ & -0.0106 \\
\hline$[0.013]$ & [0.065] & {$[0.020]$} \\
\hline-0.0044 & 0.0401 & $0.0274 *$ \\
\hline$[0.010]$ & {$[0.050]$} & [0.015] \\
\hline-0.0170 & 0.0774 & -0.0252 \\
\hline$[0.012]$ & {$[0.072]$} & [0.019] \\
\hline
\end{tabular}

$[0.020]$
-0.0411

$[0.044]$
0.0269

$[0.059]$
0.0182
$[0.064]$
-0.0552
$[0.045]$
0.0315
$[0.052]$
-0.0541

$[0.045]$
0.0535
$[0.048]$
$-0.1144 * *$

$[0.057]$
$0.1745 * * *$
$[0.051]$
-0.0334
$[0.050]$
$-0.1628^{* *}$
$[0.067]$

\begin{tabular}{c|} 
[0.003] \\
$0.0231^{* *}$ \\
{$[0.011]$} \\
$0.1019^{* * *}$ \\
{$[0.011]$} \\
$-0.0306^{* *}$ \\
{$[0.015]$} \\
$-0.0150^{*}$ \\
{$[0.008]$} \\
0.0036 \\
{$[0.008]$} \\
-0.0080 \\
\\
{$[0.015]$} \\
-0.0005 \\
\\
{$[0.015]$} \\
-0.0182 \\
{$[0.012]$} \\
-0.0173 \\
{$[0.012]$} \\
$0.0244^{*}$ \\
{$[0.015]$} \\
-0.0146 \\
{$[0.009]$} \\
\end{tabular}

$[0.017]$
0.0559
$[0.073]$
0.0185
$[0.093]$
0.0838
$[0.081]$
0.0125
$[0.044]$
-0.0094
$[0.047]$
0.0051

$[0.070]$
-0.0580

$[0.075]$
-0.0849
$[0.072]$
0.0997
$[0.065]$
$0.2279 * *$
$[0.092]$
0.0332
$[0.044]$

$[0.004]$
0.0153
$[0.016]$
$0.0979^{* * *}$
$[0.018]$
$-0.0624^{* *}$
$[0.024]$
0.0100
$[0.013]$
$0.0232^{* *}$
$[0.011]$
-0.0193

$[0.023]$
0.0004
$[0.023]$
-0.0195
$[0.019]$
-0.0051
$[0.018]$
0.0124
$[0.022]$
-0.0031
$[0.015]$

[0.017] 0.0561

[0.057]

0.0395

[0.056]

0.0548

[0.084]

$-0.0005$

[0.045]

$-0.1169 * *$

[0.054]

$0.1982^{* * *}$

[0.073]

$-0.1978^{* * *}$

[0.076]

$-0.0785$

[0.059]

0.0567

[0.064]

$-0.0177$

[0.072]

0.0444

[0.058] 


\begin{tabular}{|c|c|c|c|c|c|c|c|c|}
\hline $\begin{array}{l}\text { Disagreement in answers to all } \\
\text { decisions by fathers and mothers }\end{array}$ & $\begin{array}{c}-0.0017^{* * *} \\
{[0.001]}\end{array}$ & $\begin{array}{l}-0.0005 \\
{[0.004]}\end{array}$ & $\begin{array}{l}-0.0012 \\
{[0.001]}\end{array}$ & $\begin{array}{l}-0.0010 \\
{[0.002]}\end{array}$ & $\begin{array}{l}-0.0000 \\
{[0.000]}\end{array}$ & [0.003] & $\begin{array}{c}-0.0003 \\
{[0.001]}\end{array}$ & {$[0.002]$} \\
\hline Constant & $\begin{array}{c}0.4895 * * * \\
{[0.053]}\end{array}$ & $\begin{array}{l}0.0444 \\
{[0.318]}\end{array}$ & $\begin{array}{c}0.7166^{* * *} \\
{[0.079]}\end{array}$ & $\begin{array}{c}0.6833^{* *} \\
{[0.303]}\end{array}$ & $\begin{array}{c}0.5042^{* * *} \\
{[0.053]}\end{array}$ & $\begin{array}{l}-0.1546 \\
{[0.338]}\end{array}$ & $\begin{array}{c}0.7664^{* * *} \\
{[0.081]}\end{array}$ & $\begin{array}{c}0.6234^{* *} \\
{[0.268]}\end{array}$ \\
\hline Observations & 12,880 & 407 & 5,311 & 446 & 13,525 & 458 & 5,479 & 487 \\
\hline R-squared & 0.224 & 0.347 & 0.272 & 0.471 & 0.225 & 0.264 & 0.268 & 0.396 \\
\hline Number of hhid2 & 7,367 & 238 & 2,943 & 271 & 7,649 & 262 & 3,013 & 292 \\
\hline F test & 38.42 & . & . & . & 43.08 & . & . & . \\
\hline prob $>F$ & 0.000 & 0.000 & 0.000 & 0.000 & 0.000 & 0.000 & 0.000 & 0.000 \\
\hline
\end{tabular}




\section{References}

1. Abadian, S. (1996). Women's autonomy and its impact on fertility. World Development, 24(12), 1793-1809. doi:http://dx.doi.org/10.1016/S0305-750X(96)00075-7

2. Adato, M., Brière, B. d. I., Mindek, D., \& Quisumbing, A. R. (2003). The Impact of PROGRESA on Women's Status and Intrahousehold Relations. In A. R. Quisumbing (Ed.), Household Decisions, Gender, and Development A Synthesis of Recent Research (pp. 213-218). Washington D.C.: International Food Policy Research Institute.

3. Agarwal, B. (1997). "Bargaining" and Gender Relations: Within and Beyond the Household. Feminist Economics, 3(1), 1-51. doi:10.1080/135457097338799

4. Aizer, A. (2010). The Gender Wage Gap and Domestic Violence. The American Economic Review, 100(4), 1847-1859. doi:10.1257/aer.100.4.1847

5. Andersen, S., Bulte, E., Gneezy, U., \& List, J. A. (2008). Do Women Supply More Public Goods than Men? Preliminary Experimental Evidence from Matrilineal and Patriarchal Societies. The American Economic Review, 98(2), 376-381. doi:10.2307/29730050

6. Anderson, S., \& Eswaran, M. (2009). What determines female autonomy? Evidence from Bangladesh. Journal of Development Economics, 90(2), 179-191.

7. Ashraf, N. (2009). Spousal Control and Intra-Household Decision Making: An Experimental Study in the Philippines. American Economic Review, 99(4), 1245-1277.

8. Astuti, T. M. P. (2005). A Way of Reconstructing Lives: The Case of Women Migrants at Grobogan, Central Java. In E. K. Poerwandari (Ed.), Indonesian Women in Changing Society: Ewha Womans University Press. 
9. Bartley, S. J., Blanton, P. W., \& Gilliard, J. L. (2005). Husbands and wives in dual-earner marriages: Decision-making, gender role attitudes, division of household labor, and equity. Marriage \& Family Review, 37(4), 69-94.

10. Basu, K. (2006). Gender and Say: A Model of Household Behaviour with Endogenously Determined Balance of Power. Economic Journal, 116(511), 558-580. doi:10.1111/j.1468-0297.2006.01092.x

11. Basu, A.M., \& Koolwal, G.B. (2005). Two concepts of female empowerment-Some leads from DHS data on women's status and reproductive health. A focus on gender-Collected papers on gender using DHS data, ORC Macro, Calverton MD, 15-33.

12. Basu, K. \& Ray, R. (2002). The Collective Model of the Household and An Unexpected Implication for Child Labor: Hypothesis and an Empirical Test. Retrieved from

13. Becker, G. S. (1974). A Theory of Marriage: Part II. The Journal of Political Economy, 82(2), S11-S26.

14. Becker, G. S. (1981). Altruism in the Family and Selfishness in the Market Place. Economica, 48(189), 1-15.

15. Beegle, K., Frankenberg, E., \& Thomas, D. (2001). Bargaining Power Within Couples and Use of Prenatal and Delivery Care in Indonesia. Santa Monica, CA: RAND Corporation.

16. Blackburn, S. (2004). Women And The State In Modern Indonesia: Cambridge University Press.

17. Blackwood, E. (1995). Senior Women, Model Mothers, and Dutiful Wives: Managing Gender Contradictions in a Minangkabau Village. In A. Ong \& M. G. Peletz (Eds.), Bewitching women, pious men : gender and body politics in Southeast Asia (pp. x, 309 p). Berkeley: University of California Press. 
18. Blackwood, E. (2007). Not Your Average Housewife Minangkabau Women Rice Farmers in West Sumatra. In M. Ford \& L. Parker (Eds.), Women and work in Indonesia (pp. 1740). London: Routledge.

19. Blumberg, R. (1988). Income under Female versus Male Control - Hypotheses from a Theory of Gender Stratification and Data from the Third-World. Journal of Family Issues, 9(1), 51-84.

20. Brenner, S. A. (1995). Why Women Rule the Roost: Rethinking Javanese Ideologies of Gender and Self-Control. In A. Ong \& M. G. Peletz (Eds.), Bewitching women, pious men : gender and body politics in Southeast Asia (pp. x, 309 p). Berkeley: University of California Press.

21. Bulbeck, C. (1997). Re-orienting Western Feminisms: Women's Diversity in a Postcolonial World: Cambridge University Press.

22. Buttenheim, A. M., \& Nobles, J. (2009). Ethnic diversity, traditional norms, and marriage behaviour in Indonesia. Population Studies, 63(3), 277-294. doi:10.1080/00324720903137224

23. Chadwick, R. J. (1991). Matrilineal Inheritance and Migration in a Minangkabau Community. Indonesia(51), 47-81. doi:10.2307/3351065

24. de la Briere, B., Hallman, K., \& Quisumbing, A. R. (2003). Resource Allocation and Empowerment of Women in Rural Bangladesh. In A. R. Quisumbing (Ed.), Household Decisions, Gender, and Development A Synthesis of Recent Research (pp. 89-93). Washington D.C.: International Food Policy Research Institute.

25. Duflo, E. (2012). Women Empowerment and Economic Development. Journal of Economic Literature, 50(4), 1051-1079. 
26. Edgell, S. (1980). Middle-Class Couples: a study of segregation, domination and inequality in marriage: Allen \& Unwin.

27. Elmhirst, R. (2000). Negotiating Gender, Kinship and Livelihood Practices in an Indonesian Transmigration Area. In J. Koning, M. Nolten, J. Rodenburg, \& R. Saptari (Eds.), Women and households in Indonesia : cultural notions and social practices (pp. 208-232). Richmond, Surrey: Curzon.

28. Esten, M. (1993). Minangkabau Tradisi dan Perubahan. Padang: Angkasa Raya Padang. 29. Felkey, A. J. (2013). Husbands, Wives and the Peculiar Economics of Household Public Goods. European Journal of Development Research, 25(3), 445-465.

30. Fernandez, A., Della Giusta, M., \& Kambhampati, U. (2015). The intrinsic value of agency: the case of Indonesia. World Development, 70, 92-107.

31. Fox, G. L., \& Murry, V. M. (2000). Gender and families: Feminist perspectives and family research. Journal of Marriage and Family, 62(4), 1160-1172.

32. Frankenberg, E., Karoly, L. A., Gertler, P., Achmad, S., Agung, I. G. N., Hatmadji, S. H., \& Sudharto, P. (1995). The 1993 Indonesian Family Life Survey: Overview and Field Report. Retrieved from Santa Monica, CA: http://www.rand.org/pubs/drafts/DRU1195z1.

33. Furuta, M., \& Salway, S. (2006). Women's position within the household as a determinant of maternal health care use in Nepal. International Family Planning Perspectives, 17-27.

34. Garikipati, S. (2008). The Impact of Lending to Women on Household Vulnerability and Women's Empowerment: Evidence from India. World Development, 36(12), 2620-2642. 35. Geertz, H. (1961). The Javanese family : a study of kinship and socialization. New York: Free Press of Glencoe. 
36. Gneezy, U., Leonard, K. L., \& List, J. A. (2009). Gender Differences in Competition: Evidence From a Matrilineal and a Patriarchal Society. Econometrica, 77(5), 1637-1664. doi:10.3982/ECTA6690

37. Gray-Little, B. \& Burks, N. (1983). Power and satisfaction in marriage: A review and critique. Psychological Bulletin, 93(3), 513.

38. Hatley, B. (1990). Theatrical Imagery and Gender Ideology in Java. In J. M. Atkinson \& S. Errington (Eds.), Power and Difference: Gender in Island Southeast Asia: Stanford University Press.

39. Hoddinott, J., \& Haddad, L. (1991). Household Expenditure, Child Anthropometric Status and the Intra-household Division of Income: Evidence from the Cote d'Ivoire. Retrieved from

40. Hoddinott, J., \& Haddad, L. (1995). Does Female Income Share Influence Household Expenditures? Evidence from Cote D'Ivoire. Oxford Bulletin of Economics \& Statistics, 57(1), 77-96.

41. Ihromi, T. O. (2005). Observations Regarding Kinship Structure in Some Ethnic Indonesian Groups. In E. K. Poerwandari (Ed.), Indonesian Women in Changing Society: Ewha Womans University Press.

42. Imai, K. S., Annim, S. K., Kulkarni, V. S., \& Gaiha, R. (2014). Women's Empowerment and Prevalence of Stunted and Underweight Children in Rural India. World Development, 62(0), 88-105. doi:http://dx.doi.org/10.1016/j.worlddev.2014.05.001

43. Iversen, V. (2003). Intra-household inequality: A challenge for the capability approach? Feminist Economics, 9(2-3), 93-115. doi:10.1080/1354570032000080868 
44. Iversen, V., Jackson, C., Kebede, B., Munro, A., \& Verschoor, A. (2011). Do Spouses Realise Cooperative Gains? Experimental Evidence from Rural Uganda. World Development, Vol. 39, No. 4, 2011.

45. Jackson, C. (2013). Cooperative Conflicts and Gender Relations: Experimental Evidence from Southeast Uganda. Feminist Economics, 19(4), 25-47.

46. James, E., King, E. M., \& Suryadi, A. (1996). Finance, management, and costs of public and private schools in Indonesia. Economics of Education Review, 15(4), 387-398. doi:http://dx.doi.org/10.1016/S0272-7757(96)00035-0

47. Jejeebhoy, S. J. (2002). Convergence and Divergence in Spouses' Perspectives on Women's Autonomy in Rural India. Studies in Family Planning, 33(4), 299-308.

48. Jones, G. W. (2002). The Changing Indonesian Household. In K. Robinson \& S. Bessell (Eds.), Women in Indonesia: Gender, Equity and Development (pp. 219-234). Singapore: Institute of Southeast Asian Studies

49. Kabeer, N. (1997). Women, Wages and Intra-household Power Relations in Urban Bangladesh. Development and Change, 28(2), 261-302. doi:10.1111/1467-7660.00043

50. Kabeer, N. (1999). Resources, agency, achievements: reflections on the measurement of women's empowerment. Development and Change, 30(3), 435-464.

51. Kabeer, N. (2001). Conflicts Over Credit: Re-Evaluating the Empowerment Potential of Loans to Women in Rural Bangladesh. World Development, 29(1), 63-84.

52. Kambhampati, U. S. (2009). Child schooling and work decisions in India: the role of household and regional gender equity. Feminist Economics, 15(4), 77-112.

53. Kattan, R. B., \& Burnett, N. (2004). User Fees in Primary Education. Retrieved from

54. Keeler, W. (1990). Speaking of Gender in Java. In J. M. Atkinson \& S. Errington (Eds.), Power and Difference: Gender in Island Southeast Asia: Stanford University Press. 
55. Kevane, M., \& Levine, D. I. (2000). The Changing Status of Daughters in Indonesia. Retrieved from California: http://ideas.repec.org/p/cdl/indrel/319.html

56. King, K., McGrath, S., \& Rose, P. (2007). Beyond the basics: Educating and Training Out of Poverty. International Journal of Educational Development, 27(4), 349-357.

57. Koning, J. (2004). Generations of Change: Migration, Family Life, and Identity Formation in a Javanese Village during the New Order. Yogyakarta: Gadjah Mada University Press.

58. Koning, J., Nolten, M., Rodenburg, J., \& Saptari, R. (Eds.). (2000). Women and households in Indonesia : cultural notions and social practices. Richmond, Surrey: Curzon.

59. Kreager, P., \& Schroder-Butterfill, E. (2009). Ageing and Gender Preferences in Rural Indonesia. Retrieved from Southampton:

60. Krier, J. (1995). Narrating Herself: Power and Gender in a Minangkabau Woman's Tale of Conflict. In A. Ong \& M. G. Peletz (Eds.), Bewitching women, pious men : gender and body politics in Southeast Asia (pp. x, 309 p). Berkeley: University of California Press.

61. Kritz, M. M., \& Makinwa-Adebusoye, P. (1999). Determinants of Women's DecisionMaking Authority in Nigeria: The Ethnic Dimension. Sociological Forum, 14(3), 399-424.

62. Lange, S., \& Worrell, J. (1990). Satisfaction and commitment in lesbian and heterosexual relationships. Paper presented at the annual meeting of the American Psychological Association, Boston.

63. Mabsout, R., \& van Staveren, I. (2010). Disentangling Bargaining Power from Individual and Household Level to Institutions: Evidence on Women's Position in Ethiopia. World Development, 38(5), 783-796. 
64. Mullany, B. C., Hindin, M. J., \& Becker, S. (2005). Can women's autonomy impede male involvement in pregnancy health in Katmandu, Nepal? Social Science \& Medicine, 61(9), 1993-2006.

65. Noerdin, E. (2002). Customary Institutions, Syariah Law and the Marginalisation of Indonesian Women. In K. Robinson \& S. Bessell (Eds.), Women in Indonesia: Gender, Equity and Development (pp. 284). Singapore: Institute of Southeast Asian Studies

66. O'Shaughnessy, K. (2009). Gender, State and Social Power in Contemporary Indonesia : Divorce and Marriage Law. London; New York: Routledge.

67. Park, C. (2003). Interhousehold Transfers between Relatives in Indonesia: Determinants and Motives. Economic Development and Cultural Change, 51(4), 929-944.

68. Pfau-Effinger, B. (1998). Gender cultures and the gender arrangement-a theoretical framework for cross-national gender research. Innovation: The European Journal of Social Science Research, 11(2), 147-166. doi:10.1080/13511610.1998.9968559

69. Pfau-Effinger, B. (2004). Socio-historical paths of the male breadwinner model - an explanation of cross-national differences1. The British Journal of Sociology, 55(3), 377399. doi:10.1111/j.1468-4446.2004.00025.x

70. Portier, M. K., \& Slaats, H. (1987). Women and the Division of Parental Land in Karo Society. In R. Carle (Ed.), Cultures and societies of North Sumatra: D. Reimer.

71. Quisumbing, A. R. (Ed.) (2003). Household Decisions, Gender, and Development A Synthesis of Recent Research. Washington D.C.: International Food Policy Research Institute.

72. Quisumbing, A. R., \& Maluccio, J. A. (1999). Intrahousehold Allocation and Gender Relations: New Empirical Evidence. Retrieved from 
73. Rahman, A. (2013). Does A Wife's Bargaining Power Provide More Micronutrients to Females Evidence from Rural Bangladesh. Retrieved from

74. Rahman, M. M., Mostofa, M. G., \& Hoque, M. A. (2014). Women's household decisionmaking autonomy and contraceptive behavior among Bangladeshi women. Sexual \& Reproductive Healthcare, 5(1), 9-15. doi:http://dx.doi.org/10.1016/j.srhc.2013.12.003

75. Rammohan, A., \& Johar, M. (2009). The Determinants of Married Women's Autonomy in Indonesia. Feminist Economics, 15(4), 31 - 55.

76. Rammohan, A., \& Robertson, P. (2012). Do Kinship Norms Influence Female Education? Evidence from Indonesia. Oxford Development Studies, 40(3), 283-304. doi:10.1080/13600818.2012.711303

77. Reenen, J. (2000). The Salty Mouth of a Senior Woman: Gender and the House in Minangkabau. In J. Koning, M. Nolten, J. Rodenburg, \& R. Saptari (Eds.), Women and households in Indonesia : cultural notions and social practices. Richmond, Surrey: Curzon

78. Rodenburg, J. (2000). Staying Behind: Conflict and Compromise in Toba Batak Migration. In J. Koning, M. Nolten, J. Rodenburg, \& R. Saptari (Eds.), Women and households in Indonesia : cultural notions and social practices (pp. xiii, 354 p.). Richmond, Surrey: Curzon.

79. Rosenbluth, S. C., Steil, J. M., \& Whitcomb, J. H. (1998). Marital Equality What Does It Mean? Journal of Family Issues, 19(3), 227-244.

80. Safilios-Rothschild, C. (1970). The Study of Family Power Structure: A Review 1960-1969. Journal of Marriage and Family, 32(4), 539-552.

81. Sakai, M. (2010). Growing together in partnership: Women's views of the business practices of an Islamic Savings and Credit Cooperative (Baitul Maal wat Tamwil) in Central Java, Indonesia. Women's Studies International Forum, 33(4), 412-421. 
82. Sanday, P. R. (2002). Women at the Center : Life in a Modern Matriarchy. Ithaca, N.Y. ; London: Cornell University Press.

83. Saptari, R. (2000). Women, Family and Household: Tensions in Culture and Practice. In J. Koning, M. Nolten, J. Rodenburg, \& R. Saptari (Eds.), Women and households in Indonesia : cultural notions and social practices (pp. 10-27). Richmond, Surrey: Curzon.

84. Schwede, L. (1991). Family Strategies of Labor Allocation and Decision-making in a Matrilineal, Islamic Society: The Minangkabau of West Sumatra, Indonesia. (Degree of Doctor of Philosophy), Cornell University, New York.

85. Seebens, H., \& Sauer, J. (2007). Bargaining power and efficiency-rural households in Ethiopia. Journal of International Development, 19(7), 895-918. doi:10.1002/jid.1347

86. Sen, A. (1987a). Gender and Cooperative Conflicts. Helsinki: WIDER Publications.

87. Sen, A. (1987b). On ethics and economics. Oxford: Basil Blackwell.

88. Sen, A. (1990). Gender and Cooperative Conflicts. In I. Tinker (Ed.), Persistent Inequalities Women and World Development (pp. 123-149). Oxford: Oxford University Press.

89. Sen, A. (1985). Well-Being, Agency and Freedom: The Dewey Lectures 1984. The Journal of Philosophy, 82(4), 169-221.

90. Sen, A. (2001). Development as freedom. Oxford ; New York: Oxford University Press.

91. Sen, K. (1998). Indonesian Women at Work: Reframing the Subject. In K. Sen \& M. Stivens (Eds.), Gender and Power in Affluent Asia (pp. 323p.). London ; New York: Routledge.

92. Statistics Indonesia, B. P. S. B., \& Macro International. (2008). Indonesia Demographic and Health Survey 2007. Retrieved from Calverton, Maryland USA: 
93. Steil, J. M., \& Weltman, K. (1991). Marital inequality: The importance of resources, personal attributes, and social norms on career valuing and the allocation of domestic responsibilities. Sex Roles, 24(3-4), 161-179.

94. Story, W. T., \& Burgard, S. A. (2012). Couples' reports of household decision-making and the utilization of maternal health services in Bangladesh. Social Science \& Medicine, 75(12), 2403-2411.

95. Strauss, J., Witoelar, F., Sikoki, B., \& Wattie, A. M. (2009). The Fourth Wave of the Indonesia Family Life Survey (IFLS4): Overview and Field Report. Retrieved from

96. Thomas, D. (1990). Intra-Household Resource Allocation: An Inferential Approach. The Journal of Human Resources, 25(4), 635-664. doi:10.2307/145670

97. Thomas, D. (1993). The Distribution of Income and Expenditure within the Household. Annals of Economics and Statistics / Annales d'Économie et de Statistique (29), 109-135.

98. Weix, G. G. (2000). Hidden Managers at Home: Elite Javanese Women Running New Order Family. In J. Koning, M. Nolten, J. Rodenburg, \& R. Saptari (Eds.), Women and households in Indonesia: cultural notions and social practices (pp. 299-314). Richmond, Surrey: Curzon.

99. Wolf, D. (2000). Beyond Women and the Household in Java Re-examining the Boundaries. In J. Koning, M. Nolten, J. Rodenburg, \& R. Saptari (Eds.), Women and households in Indonesia: cultural notions and social practices (pp. 85-100). Richmond, Surrey: Curzon.

100. Wydick, B. (2008). Games in economic development. Cambridge; New York: Cambridge University Press. 